Have Humans Influenced Volcanic Activity on the Lower East Rift Zone of Kīlauea Volcano? A Publication Review

Open-File Report 2020-1017 
Cover. U.S. Geological Survey photograph of Kïlauea Volcano's lower East Rift Zone on June 6, 2018, looking southward by Kyle Anderson. Fountains from fissure 8 erupt lava into a broad, perched channel through the southeastern section of Leilani Estates. 


\section{Have Humans Influenced Volcanic Activity on the Lower East Rift Zone of Kīlauea Volcano? A Publication Review}

By Jim Kauahikaua and Frank Trusdell

Open-File Report 2020-1017

U.S. Department of the Interior

U.S. Geological Survey 


\section{U.S. Department of the Interior DAVID BERNHARDT, Secretary}

\section{U.S. Geological Survey James F. Reilly II, Director}

U.S. Geological Survey, Reston, Virginia: 2020

For more information on the USGS—-the Federal source for science about the Earth, its natural and living resources, natural hazards, and the environment-visit https://www.usgs.gov or call 1-888-ASK-USGS.

For an overview of USGS information products, including maps, imagery, and publications, visit https://store.usgs.gov.

Any use of trade, firm, or product names is for descriptive purposes only and does not imply endorsement by the U.S. Government.

Although this information product, for the most part, is in the public domain, it also may contain copyrighted materials as noted in the text. Permission to reproduce copyrighted items must be secured from the copyright owner.

Suggested citation:

Kauahikaua, J. and Trusdell, F., 2020, Have humans influenced volcanic activity on the lower East Rift Zone of Kīlauea Volcano? A publication review: U.S. Geological Survey Open-File Report 2020-1017, 17 p., https://doi.org/10.3133/ofr20201017.

ISSN 2331-1258 (online] 


\section{Contents}

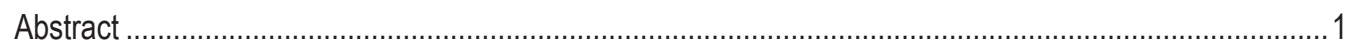

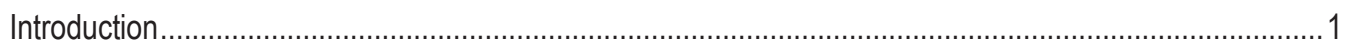

Geologic Record of Kīlauea Lower East Rift Zone Volcanic Activity .......................................................

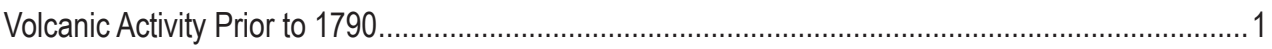

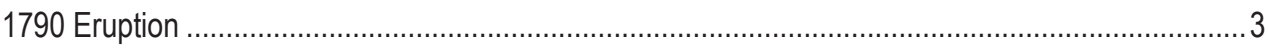

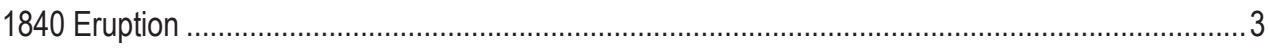

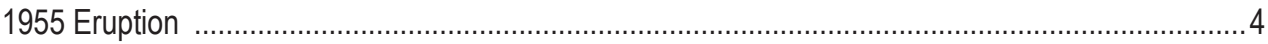

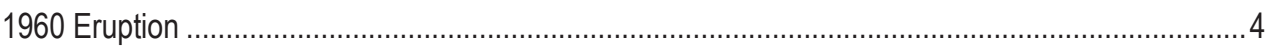

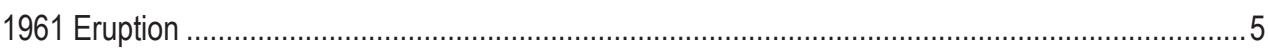

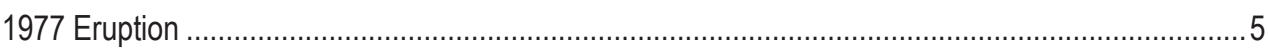

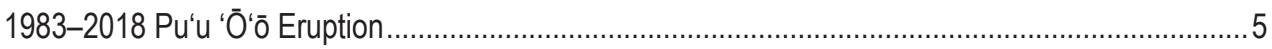

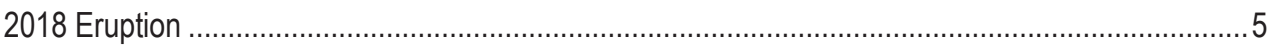

Probability, Frequency Estimates of Lava Inundation and Coverage in the LERZ …...............................

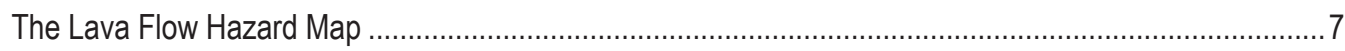

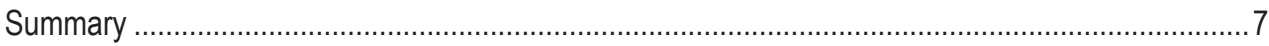

Geophysical Expressions of the Kïlauea LERZ

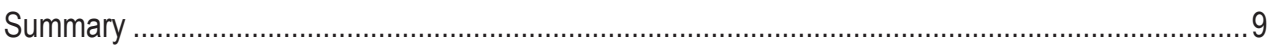

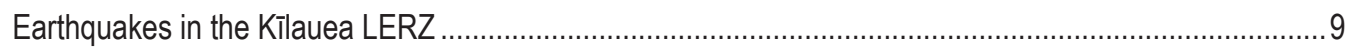

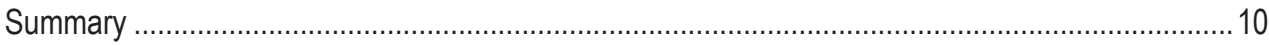

Ground Deformation in the Kîlauea LERZ

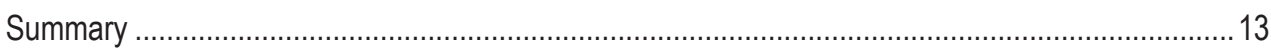

Groundwater Studies in the Kïlauea LERZ

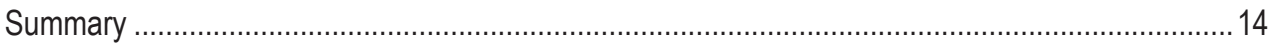

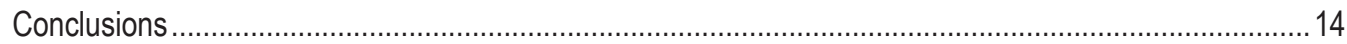

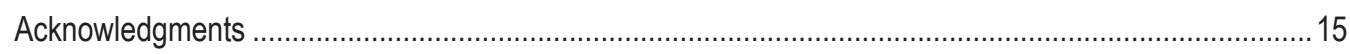

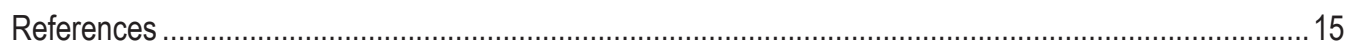

\section{Figures}

1. Map of the lower East Rift Zone of Killauea Volcano showing the lava flows from eight eruptions over the past 250 years .............................................................................

2. Perspective three-dimensional map of the 1840 lava flow (red) from the lower East Rift Zone of Kïlauea and its offshore extension..........................................................................

3. Map of the lower East Rift Zone showing the 2018 lava flows in pink and the 3 Geothermal Subzones (tan polygons) for which 50-year probabilities of lava inundation (60-65 percent)

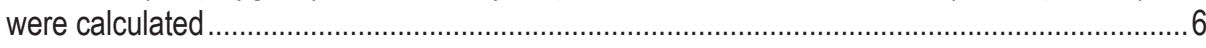

4. Map showing the 2018 lava flows (pink) plotted over the lava flow hazard zone map of

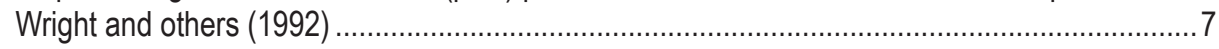

5. Plot of earthquake occurrence of a given magnitude according to the Gutenberg-Richter relation, modified from figure 4 of Kenedi and others (2010) .............................................. 10

6. Map showing the locations of earthquakes detected during two important seismic surveys on the lower East Rift Zone of Kilauea Volcano.............................................................. 11

7. Plots of movement of the Global Positioning System monument WAPM from installation in 2004 to removal in May 2018 


\section{Abbreviations}

$\begin{array}{ll}\text { asl } & \text { above sea level } \\ \text { BP } & \text { before present } \\ \mathrm{ft} & \text { feet } \\ \text { gal } & \text { gallon } \\ \text { in } & \text { inch } \\ \mathrm{km} & \text { kilometer } \\ \mathrm{km}^{2} & \text { square kilometers } \\ \mathrm{km}^{3} & \text { cubic kilometers } \\ \mathrm{LERZ}^{2} & \text { lower East Rift Zone } \\ \mathrm{m} & \text { meter } \\ \mathrm{m}^{2} & \text { square meters } \\ \mathrm{m}^{3} & \text { cubic meters } \\ \mathrm{mi}^{2} & \text { mile } \\ \mathrm{mi}^{2} & \text { square miles } \\ \mathrm{mi}^{3} & \text { cubic miles } \\ \mathrm{nT} & \text { nanoTesla } \\ \mathrm{SP} & \text { self-potential } \\ \mathrm{Vp} & \text { seismic compressional wave velocity } \\ \mathrm{Vs} & \text { seismic shear wave velocity } \\ \mathrm{yd} & \text { cubic yards } \\ \mathrm{yr}^{3} & \text { years } \\ \end{array}$




\title{
Have Humans Influenced Volcanic Activity on the Lower East Rift Zone of Kïlauea Volcano? A Publication Review
}

\author{
By Jim Kauahikaua and Frank Trusdell
}

\begin{abstract}
Since the 2018 eruption of Killauea Volcano, the topic of whether commercial developments not only caused the eruption to occur in the lower East Rift Zone (LERZ), but also caused its high eruption rate has been a subject of public discussion. We review Kîlauea Volcano publications from the past several decades and show that the eruptive behavior of the volcano has varied and that the 2018 eruption was similar to past eruptions in many ways. We find no evidence to support any human influence on Kīlauea Volcano.
\end{abstract}

\section{Introduction}

Questions about the relation between human activity or developments and active Hawaiian volcanoes usually are raised during eruptions. These concerns often regard the location of an industrial development, like a geothermal power generation facility, on a volcano (for example, Big Island Video News, 2019; Firozi, 2018). Since the 2018 eruption, the topic of whether commercial developments not only caused the eruption to occur in Kîlauea's lower East Rift Zone (LERZ), but also caused it to erupt with a higher-than-normal rate has been a subject of public discussion.

In this report, we address this topic by examining whether volcanic activity has changed significantly in the past few decades owing to the large increase in population and the development of modern agriculture and subsurface geothermal resources in the LERZ part of the Puna District (defined here as the area east of $155^{\circ}$ longitude for this report).

In the LERZ, geologic information is available for the past millennia, but the record is probably incomplete beyond a few centuries from the present. However, the LERZ was also the focus of geothermal exploration and thus many studies in the 1970s and 1980s provided a geophysical and hydrological record of the volcano's activity for the past several decades.

Here we review existing publications to establish what is geologically, geophysically, and hydrologically known about the LERZ of Kîlauea Volcano. Many quotes are used to convey cited authors' ideas directly to the reader and the results are briefly summarized for each section.

\section{Geologic Record of Kîlauea Lower East Rift Zone Volcanic Activity}

Over the past 250 years, there have been eight eruptions that produced lava flows in the lower East Rift Zone (LERZ; east of $155^{\circ}$ longitude) of Kīlauea Volcano, all involving discharge of lava from multiple fissures. Six of the eruptions — 1790, 1840, 1955, 1960, 1961, and 2018 - came from vents in the LERZ (fig.1). Lava-flow and fissure map data for the five pre-2018 events are available from Orr (2018). Two eruptions prior to 1790 in this area posed significant hazards and are also worth noting to get an accurate sense of the range of lower East Rift Zone eruption characteristics. Written descriptions are available for the 1840 and later eruptions.

\section{Volcanic Activity Prior to 1790}

Moore (1992, p. 480) summarized significant LERZ activity over the past 750 years:

One voluminous eruption during this time interval formed the spatter cone of Puu Kaliu ..., associated small spatter ramparts, and thick aa flows. The right-stepping eruptive fissure extends about $1.5 \mathrm{~km}$ along the southern side of the LERZ. Aa flows, commonly $15 \mathrm{~m}$ or more thick, covered at least $12 \mathrm{~km}^{2}$. The estimated volume of the Puu Kaliu eruption is about $0.2 \mathrm{~km}^{3}$.

The Kali'u eruption (older than 490 years [yr] BP) flowed south and entered the ocean in two branches that are each now partially covered by younger lava flows (Moore and Trusdell, 1991). The west flow branch was at least 1.4 kilometers (km; 0.9 miles [mi]) wide at the coast, and the fan-shaped coastline suggests that the eruption built a lava delta approximately 300 meters (m; 1,000 feet [ft]) into the ocean. Bathymetry extending about $1 \mathrm{~km}(0.6 \mathrm{mi})$ offshore is available and shows the offshore slopes progressively steepen; however, without pre-eruption topography, the volume of offshore eruption deposits cannot be accurately estimated. 


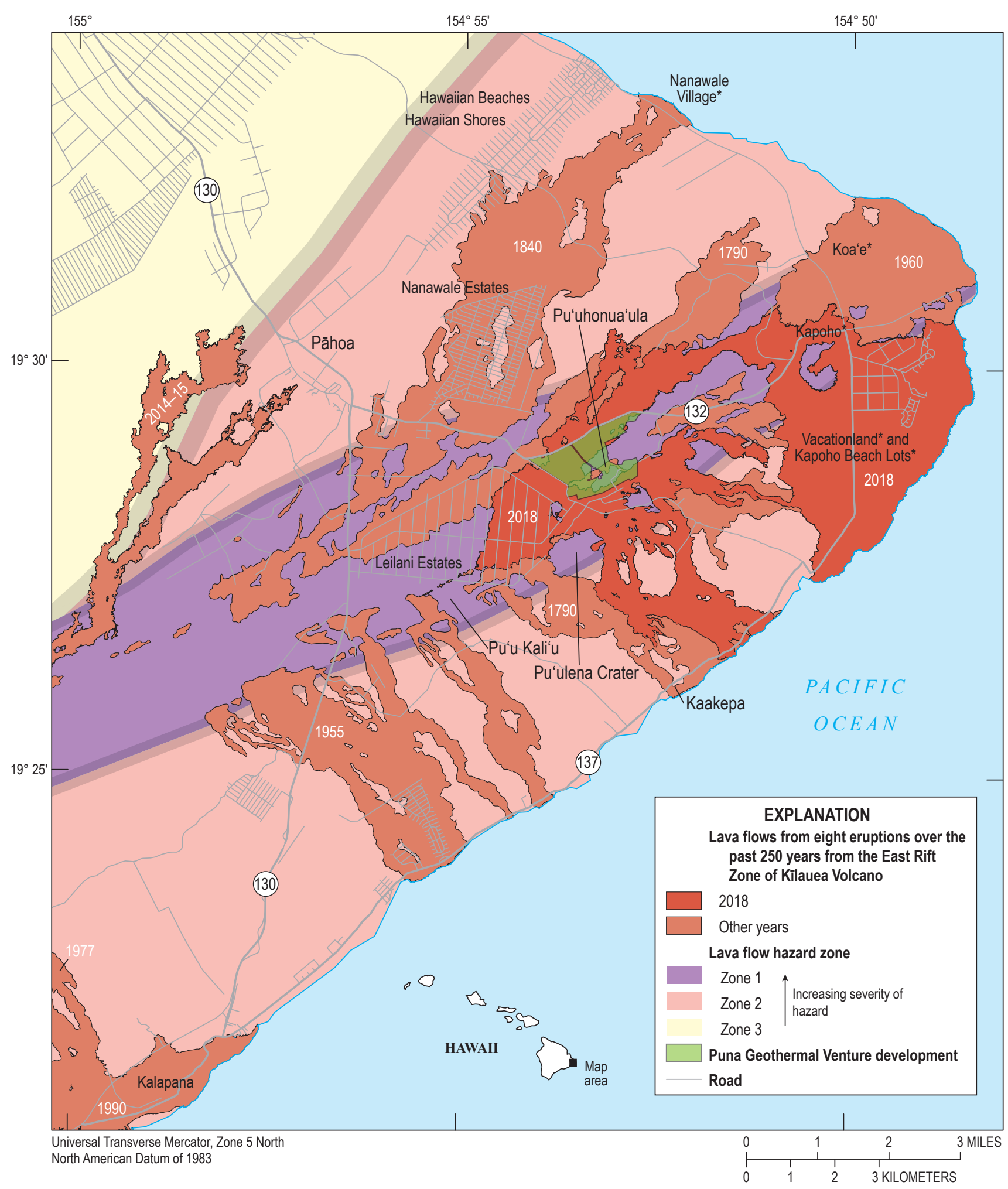

Figure 1. Map of the lower East Rift Zone of Killauea Volcano showing the lava flows from eight eruptions over the past 250 years (in different shades of red), which are plotted over the Lava Flow Hazard Map (Wright and others, 1992). Lava Flow Hazard Zone 1 is in purple, Zone 2 is in salmon-color, and Zone 3 is in yellow. Place names followed by asterisks no longer exist. The green, semi-transparent polygon near the center of the figure is the Puna Geothermal Venture development. Hazard zone boundaries are approximate. The change in the degree of hazard from one zone to the next is generally gradual rather than abrupt, and the change can occur over the distance of a mile or more. Within a single hazard zone, the severity of hazard may vary on a scale too fine to map. These variations may be the result of gradual changes that extend across the entire zone. For example, the hazard posed by lava flows decreases gradually as the distance from vents increases. 
Moore's (1992, p. 480) summarization of significant LERZ activity continues:

An unusual eruption during this time interval resulted in deposition of unconsolidated, unstratified, lithic-rich tuff near Puulena [sic] Crater in the central LERZ ... Discontinuous exposures of tuff extend across more than $4 \mathrm{~km}^{2}$, overlie a spatter cone dated at $1270 \pm 70$ years $\mathrm{BP}$, and underlie the lava flow dated at $490 \pm 60$ years BP. Tuff as thick as $20 \mathrm{~m}$ was deposited during violent phreatic eruptions that probably resulted when ascending magma encountered perched groundwater or a hydrothermal reservoir. Collapse near the end of the phreatic explosions formed the three largest pit craters, including Puulena [sic] Crater, on the LERZ.

$\mathrm{Pu}^{\prime} \mathrm{u}$ Kali' $u$ is located on the southern boundary and Pu'ulena Crater is located on the southeastern boundary of Leilani Estates.

\section{Eruption}

What is known about the eruption of 1790 was summarized by Moore (1992, p. 481) as:

Voluminous eruptions around $1790 \ldots$..., including at least $0.2 \mathrm{~km}^{3}$ in the study area alone, may have contributed to caldera collapse at the summit of Kilauea [sic] (Holcomb 1987). Magma withdrawn from the reservoir underlying the summit area and intruded as dikes down virtually the entire length of the subaerial east rift zone may have resulted in an unsupported upper volcanic edifice. Two separate dikes ... were intruded in the LERZ; the eruptive fissures are $1 \mathrm{~km}$ apart at their uprift (southwestern) end but gradually diverge to about $2 \mathrm{~km}$ apart at their downrift (northeastern) end. The southern fissure system, about $8.5 \mathrm{~km}$ long, shows right-stepping en echelon displacement of individual vents for its western $6 \mathrm{~km}$; the eruptive vents then shift left (northward) and are left-stepping for the last $2.5 \mathrm{~km}$ downrift. The northern 1790 eruptive fissure is mostly left-stepping throughout its $13 \mathrm{~km}$ length. Flows from the two eruptive fissures are not in contact, and their relative ages cannot be determined. Flows of 1790 cover about $35 \mathrm{~km}^{2}$. A small littoral cone (Kaakepa ... .) was built where 1790 aa flowed into the ocean. Radiocarbon ages of one flow from each fissure system are $<200$ years BP.

\section{Eruption}

Each of the LERZ eruptions and summit subsidence events since 1790 have near-contemporaneous descriptions of the activity. After brief eruptions in the upper East Rift Zone, in 1840 lava erupted from five fissures over a span of $8.5 \mathrm{~km}(5.3 \mathrm{mi})$ in the LERZ. The eruption started on May 30, 1840, and lasted for 26 days. The flows entered the ocean two days after activity started and continued for another three weeks. The lava flow destroyed Nanawale village (Dana, 1849).
Titus Coan was in Honolulu, $\mathrm{O}^{\prime}$ ahu, during the entire eruption and missed all the activity. For the account below from Coan (1840, p. 283-285) relied on "credible testimony:"

After flowing under ground [sic] several miles, perhaps six or eight, it again broke out like an overwhelming flood, and sweeping forest, hamlet, plantation, and every thing [sic] before it, rolled down with resistless energy to the sea, where, leaping a precipice of forty or fifty feet, it poured itself in one vast cataract of fire into the deep below, with loud detonations, fearful hissings, and a thousand unearthly and indescribable sounds. Imagine to yourself a river of fused minerals, of the breadth and depth of Niagara, and of a deep gory red, falling, in one emblazoned sheet, one raging torrent, into the ocean! The scene, as described by eye witnesses, was terribly sublime ... The atmosphere in all directions was filled with ashes, spray, gases, etc.; while the burning lava, as it fell into the water, was shivered into millions of minute particles, and, being thrown back into the air, fell in showers of sand on all the surrounding country. The coast was extended into the sea for a quarter of a mile, and a pretty sand-beach and a new cape were formed. Three hills of scoria and sand were also formed in the sea, the lowest about two hundred and the highest about three hundred feet. For three weeks this terrific river disgorged itself into the sea with little abatement.

A century later, Stearns and Macdonald (1946, table on p. 111) deduced several features of the eruption while making the first comprehensive geologic map of the Island of Hawai' $i$. The flows covered 17 square kilometers $\left(\mathrm{km}^{2} ; 6.6\right.$ square miles $\left[\mathrm{mi}^{2}\right]$ ) and the erupted volume was estimated to be 0.215 cubic kilometers $\left(\mathrm{km}^{3} ; 281 \times 10^{6}\right.$ cubic yards $\left.\left[\mathrm{yd}^{3}\right]\right)$, which includes offshore volume estimate of $0.153 \mathrm{~km}^{3}\left(200,000,000 \mathrm{yd}^{3}\right.$; Stearns and Macdonald, 1946). Therefore, $0.062 \mathrm{~km}^{3}$ $\left(81,000,000 \mathrm{yd}^{3}\right)$ is the estimate of lava volume above sea level. We can divide this above-sea-level (asl) volume by the asl area to get the average thickness. Using the metric equivalents and doing the division $\left(62 \times 10^{6} \mathrm{~m}^{3} / 17 \times 10^{6} \mathrm{~m}^{2}\right)$, we get an average thickness of $3.6 \mathrm{~m}$.

We can use this value of thickness multiplied by the newly mapped lava flow area $\left(26.2 \mathrm{~km}^{2}\right.$ in 12 polygons from Orr, 2018) to get a revised estimate of the above sea level (asl) volume of $0.094 \mathrm{~km}^{3}$ compared to $0.062 \mathrm{~km}^{3}$ from Stearns and Macdonald (1946).

Using modern bathymetry, better estimates of the offshore volume can be made. We used the hilo2punb data set from the Puna Ridge survey (Monterey Bay Aquarium Research Institute, 1998) and the shallower bathymetry from lidar (light detection and ranging, a form of laser-measured topography and bathymetry) surveys in the area (National Oceanographic and Atmospheric Administration, 2013), drew a contact from the coastal exposure of the 1840 lava (fig. 2), and estimated the volume of the offshore lava assuming a flat flow bottom. The resulting estimate of offshore volume is at least $0.1 \mathrm{~km}^{3}\left(0.02 \mathrm{mi}^{3}\right)$ 
Figure 2. Perspective three-dimensional map of the 1840 lava flow (red) from the lower East Rift Zone of Kīlauea and its offshore extension outlined in blue. The larger offshore component, apparently connected to flow f8e2, is outlined in orange. View is looking south. The transparent zone around the shoreline is a data gap.

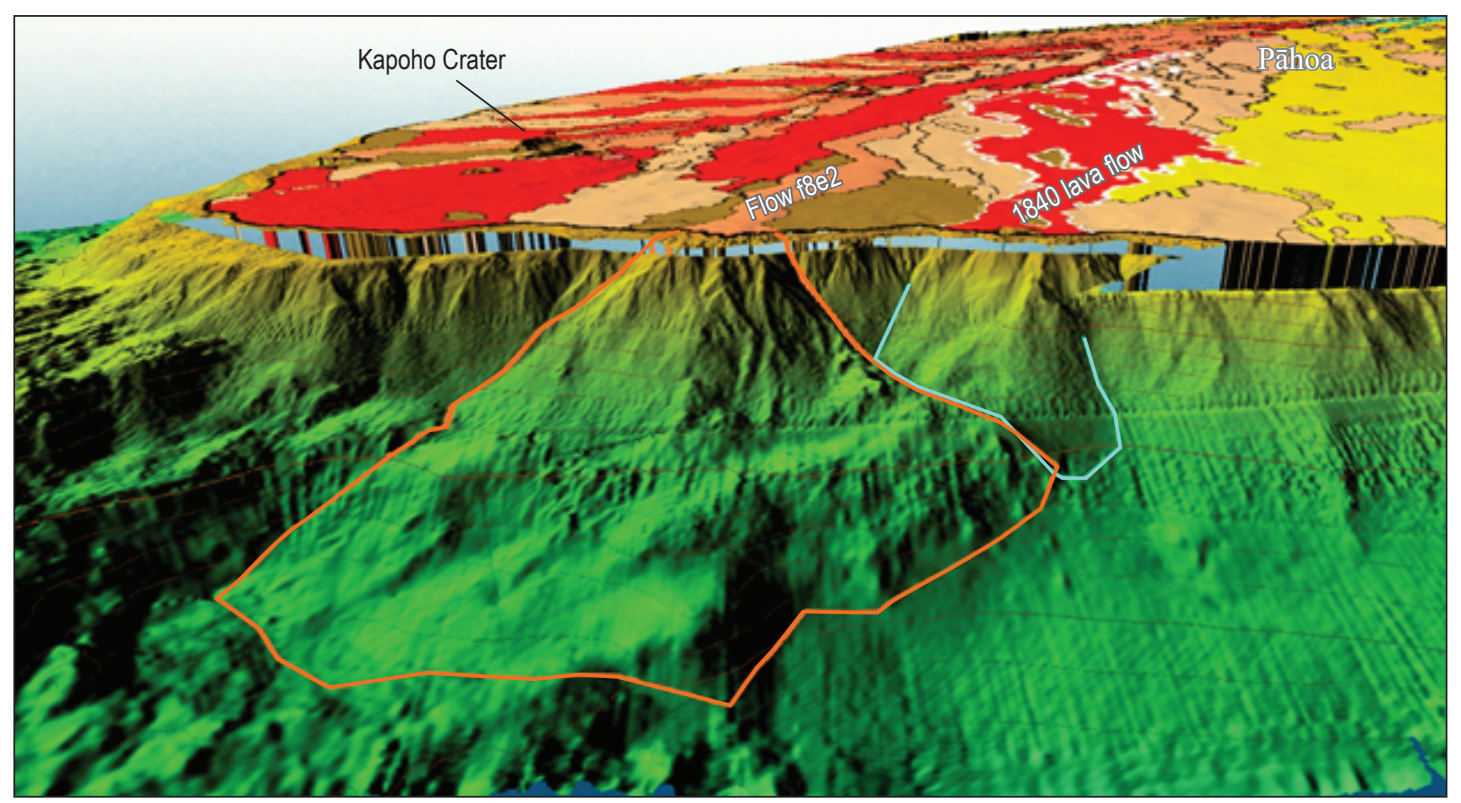

making a total erupted volume of at least $0.2 \mathrm{~km}^{3}\left(0.05 \mathrm{mi}^{3}\right)$. Dividing this total volume by the 26-day duration of the eruption, we estimate the eruption rate to be more than 90 cubic meters per second $\left(\mathrm{m}^{3} / \mathrm{s} ; 120 \mathrm{yd}^{3} / \mathrm{s}\right)$.

On the basis of more detailed geologic mapping by Moore and Trusdell (1991), Moore (1992, p. 481) summarized the 1840 eruption:

The 1840 eruption . . . extruded a small volume of . . . [lava] in the upper east rift zone and about $0.15 \mathrm{~km}^{3}$ of ... [lava] that covered about $20 \mathrm{~km}^{2}$ of the ... [LERZ]. Most vents on the LERZ occur along a 7.5-km-long segment in its northern part. In addition, five small vents erupted along a $2.8-\mathrm{km}$-long fissure $0.9 \mathrm{~km}$ north of and parallel to the main 1840 vents ... Aa from the main vents flowed to the ocean, where steam explosions built a littoral cone, Sand Hill.

Note the larger lava fan to the southeast of the 1840 offshore lava in figure 2. A source for that massive deposit is likely a small subaerial lava flow (labeled "f8e2") whose source vent was overrun by the 1790 lava flow; the flow itself is younger than $400 \mathrm{yr}$ (Moore and Trusdell, 1991). The entire offshore fan has an approximate volume of $1 \mathrm{~km}^{3}\left(0.24 \mathrm{mi}^{3}\right)$. It is beyond the scope of this paper to confirm the connection between these offshore lavas and lava flow f8e2, but the size of its assumed offshore component might dwarf the 1840 offshore lavas.

\section{Eruption}

During the 88-day Puna eruption in 1955, lava flows started along the south base of Pu'uhonua'ula, and continued from more than 20 fissures to the northeast and southwest spanning over a $14 \mathrm{~km}(8.7 \mathrm{mi})$ of the LERZ. Lava flows destroyed crops and 21 structures and entered the ocean at multiple locations.

The subaerial area of $15.8 \mathrm{~km}^{2}\left(6.1 \mathrm{mi}^{2}\right)$ is close to the $16.7 \mathrm{~km}^{2}$ area from Orr (2018). The volume of erupted lava equals $0.108 \mathrm{~km}^{3}\left(141 \times 10^{6} \mathrm{yds}^{3}\right)$. This volume included the volume of the two largest lava deltas but does not include the offshore volume beyond the deltas. Instantaneous eruption rates ranged from 0 to $130 \mathrm{~m}^{3} / \mathrm{s}\left(0\right.$ to $170 \mathrm{yd}^{3} / \mathrm{s}$; Macdonald and Eaton, 1964, fig. 28).

Using more detailed geologic mapping (Moore and Trusdell, 1991), Moore (1992, p. 481) concluded that:

The 1955 eruption . . . lasted 88 days, during which about $0.11 \mathrm{~km}^{3}$ of lava covered about $16 \mathrm{~km}^{2}$ and destroyed 21 houses. Vents formed discontinuously along a 15.8-km-long segment of the southern LERZ . . .

\section{Eruption}

During the 5-week Kapoho eruption, 12 fissures opened within a $2 \mathrm{~km}(1.2 \mathrm{mi})$ span of the LERZ and flows entered the ocean north of Kapoho Bay. Damage was significant and included crops and about 70 structures in the villages of Kapoho and Koa'e (Richter and others, 1970).

Macdonald and Abbott (1970) reported an erupted volume of $0.12 \mathrm{~km}^{3}\left(155 \times 10^{6} \mathrm{yd}^{3}\right)$ with no notes about whether this includes offshore lava. Differencing the pre- and post-1960 topography yields a subaerial volume of $0.16 \mathrm{~km}^{3}$ $\left(204 \times 10^{6} \mathrm{yd}^{3}\right)$ and a minimum submarine volume (obtained using MBARI bathymetry and NOAA topobathy lidar data) of $0.091 \mathrm{~km}^{3}\left(120 \times 10^{6} \mathrm{yd}^{3}\right)$. Therefore, the best estimate of the total erupted volume in 1960 exceeds $0.25 \mathrm{~km}^{3}\left(324 \times 10^{6} \mathrm{yd}^{3}\right)$. The time-averaged eruption rate for the 36-day event exceeds $56 \mathrm{~m}^{3} / \mathrm{s}\left(73 \mathrm{yd}^{3} / \mathrm{s}\right)$.

On the basis of more recent geologic mapping (Moore and Trusdell, 1991), Moore (1992, p. 481) summarized the eruption:

The 1960 eruption . . . occurred along a 1-km-long fissure system near Kapoho . . . It followed, after a hiatus of 25 days, the November-December 1959 eruption at Kilauea Iki [sic] on the volcano's eastern summit. Prior to the onset of the eruption, earthquake 
epicenters migrated at least $5 \mathrm{~km}$ down the LERZ to the vicinity of Kapoho. Four days after the eruption began, Kilauea's [sic] summit began to subside as magma was withdrawn from the summit reservoir. The eruption lasted 38 days and extruded about $0.125 \mathrm{~km}^{3}$ of lava that covered $10 \mathrm{~km}^{2}$ and destroyed the villages of Kapoho and Koae [sic], a US Coast Guard station, and several other residences...

\section{Eruption}

Twenty-two months after the Kapoho 1960 eruption ceased, the East Rift Zone erupted again from multiple fissures that opened about $4 \mathrm{~km}(2.5 \mathrm{mi})$ west of highway 130 . The fissures were along the trend followed by the 1790 and 1840 eruptions (Richter and others, 1964). On the basis of more recent geologic mapping of the eastern breakouts (Moore and Trusdell, 1991), Moore (1992, p. 481) summarized the eruption:

The one-day 1961 eruption ... extruded only about $250,000 \mathrm{~m}^{3}$ of lava that covered less than $1 \mathrm{~km}^{2}$ of uninhabited rain forest in the western part of the LERZ ... Eruptive vents generally are left-stepping, characteristic of others on the northern side of the LERZ.

\section{Eruption}

Moore and others (1980) described this 18-day eruption from multiple fissures that erupted a lava flow that threatened the town of Kalapana. The flow advanced to within $700 \mathrm{~m}$ of the nearest house. While the vents were west of $155^{\circ}$ longitude, the flow advanced south southeast and crossed into the LERZ before stalling.

Approximately $0.035 \mathrm{~km}^{3}\left(46 \times 10^{6} \mathrm{yd}^{3}\right)$ were erupted over the 18 days for a time-averaged eruption rate of $23 \mathrm{~m}^{3} / \mathrm{s}\left(29 \mathrm{yd}^{3} / \mathrm{s}\right)$.

\section{3-2018 Pưu ‘Ō‘ō Eruption}

The 35-year eruption occurred from vents outside the LERZ, but the flows crossed the $155^{\circ}$ longitude boundary of the LERZ into the Kalapana area in 1986, 1990 (Mattox and others, 1993), and 2010 and advanced toward Pāhoa in 2014-2015 (Poland and others, 2016).

The eruption rate was variable during this long eruption and slowly declined over the past decade (Anderson and Poland, 2016). The overall total erupted volume of approximately $4 \mathrm{~km}^{3}$ $\left(1 \mathrm{mi}^{3}\right)$ provides a time-averaged eruption rate less than $4 \mathrm{~m}^{3} / \mathrm{s}$ $\left(5 \mathrm{yd}^{3} / \mathrm{s}\right)$.

\section{Eruption}

During the 4-month 2018 eruption, 24 fissures were active within a $7 \mathrm{~km}(4.3 \mathrm{mi})$ span of the LERZ. The fissures were informally named with a number indicating the order in which they erupted. Fissure 1 erupted in the southeastern portion of Leilani Estates on May 3, 2018. Subsequent fissures opened to the northeast and the southwest of fissure 1. Fissures 20, 22, and 8 generated lava flows that reached the ocean and 723 homes were destroyed (Hawaii County, 2019).

About $1.5 \mathrm{~km}^{3}\left(2 \times 10^{9} \mathrm{yd}^{3}\right)$ of lava was erupted over 94 days for a time-averaged eruption rate of nearly $250 \mathrm{~m}^{3} / \mathrm{s}$ $\left(330 \mathrm{yd}^{3} / \mathrm{s}\right.$ dense-rock equivalent; Dietterich and others, 2019) from fissure 8 located in the eastern portion of Leilani Estates. After August 4, fissure 8 vent continued erupting an insignificant amount of lava for another month and became inactive in the first week in September 2018 (Hawaiian Volcano Observatory, 2019).

Neal and others (2018) state:

The voluminous 2018 eruptive activity probably was driven by a combination of factors, foremost among these being the pressurized pre-eruptive state of the summit and ERZ and the relatively low elevation of the eruptive vent.

\section{Probability, Frequency Estimates of Lava Inundation and Coverage in the LERZ}

The well documented geologic record for the LERZ spans several centuries. Six multifissure eruptions started within the past 250 years constitutes a relatively high eruption frequency. Assuming the past several centuries is typical for this region of Killauea Volcano, this lengthy geologic record is sufficient to use for the purpose of forecasting the likelihood of future volcanic activity in the LERZ. The rate of coverage by lava flows through time is an important measure of how quickly the surface of an active volcano is covered by lava. This measure was chosen as the basis for the Lava Flow Hazard Zone map (Heliker, 1990; Wright and others, 1992). The coverage rate is estimated by calculating the area covered during different time periods in the past starting at the present time.

Coverage rates expressed in percent theoretically rise exponentially from 0 to 100 percent with time. The coverage rate for Kỉlauea Volcano was first estimated by Holcomb (1987, p. 261) based on his geologic mapping of the volcano: "About 70 percent of Kilauea's [sic] surface is younger than 500 years, about 90 percent younger than 1,100 years [italics mine]." Geologists interpret this to mean that, if Kinlauea behaves in the future as it has in the last millennia, about 70 percent of the volcano's surface will be covered by future lava flows in the next 500 years and about 90 percent will be covered in 1,100 years. Using these data (Holcomb, 1987), approximate interpolation yields an average coverage rate of about 10 percent in 50 years for the entire volcano.

Including the 35-year eruption of $\mathrm{Pu}^{\prime} \mathrm{u}$ ' ${ }^{`}{ }^{‘} \overline{\mathrm{o}}$ and the 2018 lava flows in the most recent geologic mapping (Sherrod and others, 2007), 27 percent of Kilauea has been covered in the past 250 years with 90 percent coverage by 750 years. Interpolating these updated coverage rates, we would estimate a lower average coverage rate of about 5 percent in 50 years for the entire volcano; however, Kïlauea Volcano has been very active over the past 50 
years (1968-2018). The $\mathrm{Pu}^{‘} \mathrm{u}$ ' ${ }^{`}{ }^{`} \mathrm{o}$ eruption covered 10 percent of the volcano in 35 years and the 2018 eruption lava flows covered a little over 2 percent in 3 months. Including the Mauna Ulu (1969-1974) activity, the 1971, 1974, and 1982 activity in the caldera and the Southwest Rift Zone, and the upper East Rift Zone eruptions and the 1977 middle East Rift Zone activity resulting in lava covering about 18 percent of the surface of Killauea Volcano in the most recent 50 -year period.

Like other measures of volcanic activity, coverage rate can vary widely with time when evaluated over short intervals. For example, the average coverage rate for the 200 years before the most recent 50-year period results in a much lower rate of coverage in the prior 50-year period amounting to only a few percent for the entire 200 years.

Another way to characterize eruptive behavior of a volcano is to estimate the average frequency of its eruptions or the average repose interval between eruptions. For example, Moore (1992, p. 480-481) estimated the dormant (or repose) interval, or the length of time between eruptions, for the LERZ based on the mapping by Moore and Trusdell (1991):

"The average dormant interval, based on the known eruptions, during this time period [400-750 yrs ago] was about 6.6 years. Several more eruptions, whose products are buried by younger rocks, may have occurred."

"The average dormant interval from 1790-1961 was 42.75 years, much longer than during the period from
1500-200 years BP. Historic repose periods have varied considerably, however. No eruptions occurred in the study area between those of 1840 and 1955, and three $(1955,1960$, and 1961) occurred during a seven-year period."

By this metric, we see that eruptions have been less frequent in the past 250 years than in the 350 years before that. Moore (1992, p. 475) estimated the long-term average dormant interval for the past 1,500 years is approximately 13.6 years.

A third way to quantify the behavior of a volcano is to estimate the probability that lava will inundate a specific area during a specific period of time. This is done by tallying all the flows and their ages within the parcel in question then dividing the oldest flow age by the number of different flows mapped in the area to estimate the average dormant interval or recurrence interval. These numbers can then be used to estimate the probability of a future inundation within a given time period.

Based on the mapping and dating by Moore and Trusdell (1991), Kauahikaua and others (1994) calculated probabilities for lava inundation for each of three large land parcels, the geothermal subzones, in Puna District. The Puna geothermal subzones were areas where Hawai' $i$ County wished to direct geothermal energy exploration and development (fig. 3). The three subzones (both uprift and downrift of, but not including, Leilani Estates) represented most of the LERZ. The probability of inundation for each of these subzone parcels was 60-65 percent over any 50-year $155^{\circ}$

$154^{\circ} 55^{\prime}$

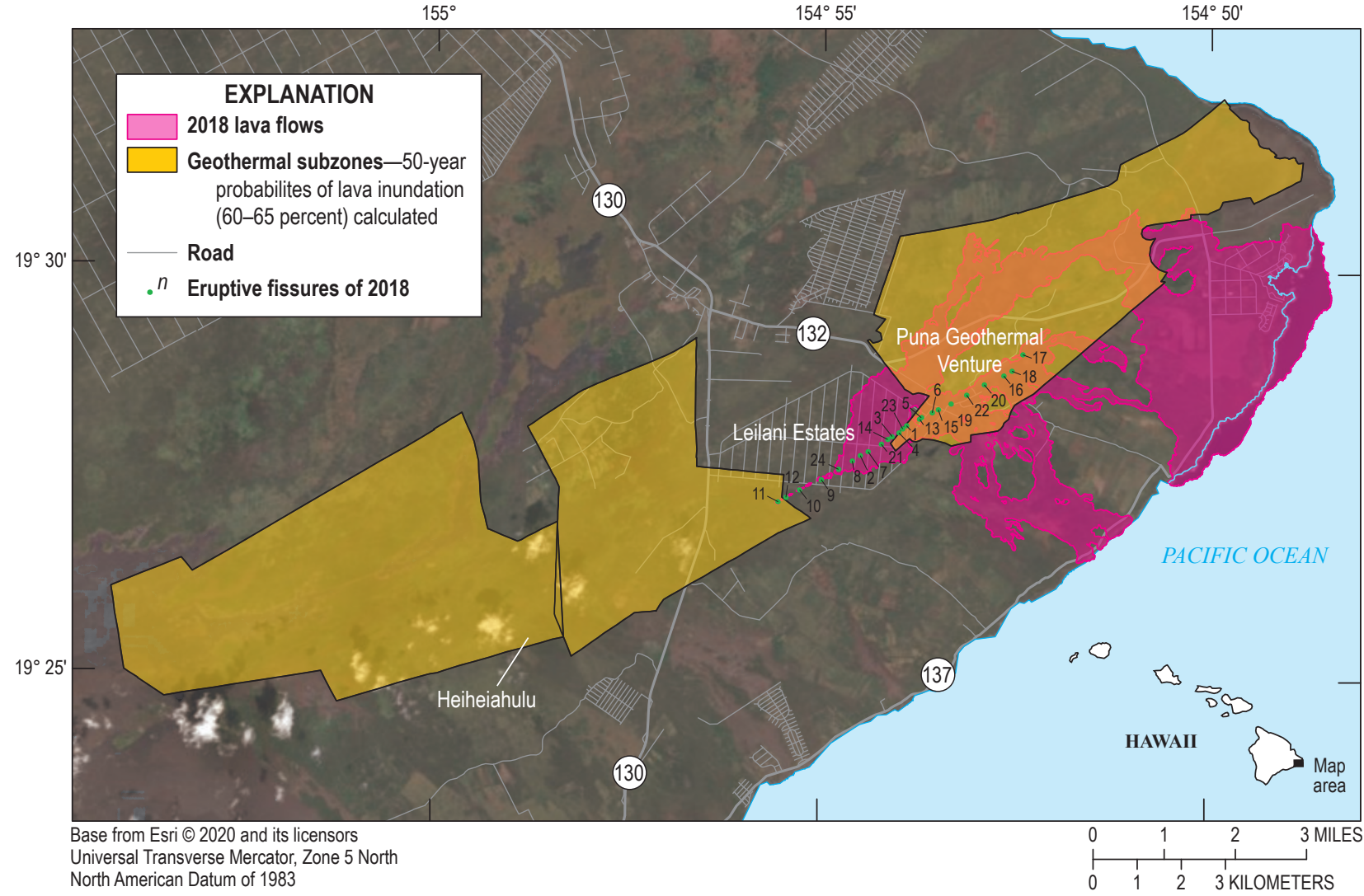

Figure 3. Map of the lower East Rift Zone showing the 2018 lava flows in pink and the 3 Geothermal Subzones (yellow polygons) for which 50-year probabilities of lava inundation (60-65 percent) were calculated (Kauahikaua and others (1994). The numbered dots along the rift zone are the 24 fissures that erupted in 2018 numbered in chronological order. 
period - fairly uniform probabilities for the lower $30 \mathrm{~km}$ of the East Rift Zone. The areas of the three subzones ranged from $22.3 \mathrm{~km}^{2}\left(8.6 \mathrm{mi}^{2}\right)$ to $37.8 \mathrm{~km}^{2}\left(14.6 \mathrm{mi}^{2}\right)$. The probabilities are theoretically higher for larger areas - basically the larger the target, the higher probability of being inundated by lava. The Leilani Estates subdivision and the PGV development have smaller areas than the geothermal subzones so their lava inundation probabilities would be lower but still significant relative to similar sized areas away from the rift zone (fig. 4).

\section{The Lava Flow Hazard Map}

The Lava Flow Hazard Map (Wright and others, 1992) is primarily based on the rate of coverage by lava flows and the structure of the volcano. Areas on the Island of Hawai' $i$ are ranked from 1 to 9 with zone 1 being the highest hazard and the most likely to be directly affected by eruptions (fig. 4).

According to Wright and others (1992), zone 1, the highest hazard zone "includes summits and rift zones of Kilauea [sic] and Mauna Loa, where vents have been repeatedly active in historical time [italics mine]." Leilani Estates and Lanipuna Gardens are both within lava flow hazard zone 1 . Coverage rates are not specifically defined for zone 1, but they are known to be higher than for zone 2 . Lava flows erupted in the past 250 years have covered more than 50 percent of lava flow hazard zone 1 on the LERZ.
According to Wright and others (1992), zone 2, the second highest hazard zone, includes "areas adjacent to and downslope of zone 1. Fifteen to twenty-five percent of zone 2 has been covered by lava since 1800 and 25 to 75 percent has been covered within the past 750 years." Lava flows erupted in the past 250 years have covered 35 percent of lava flow hazard zone 2 and less than 5 percent of lava flow hazard zone 3 in the LERZ.

Leilani Estates and Lanipuna Gardens are wholly within lava flow hazard zone 1. Nanawale Estates, Pāhoa, Hawaiian Shores, Hawaiian Beaches (fig. 1), and all residential developments south of the rift zone are within lava flow hazard zone 2. Communities around Kapoho Bay are in zones 1 and 2.

\section{Summary}

The LERZ has been the site of frequent volcanic events. In the past 1,000 years since Polynesians arrived on the Island of Hawai' $\mathrm{i}$, more than 90 percent of the surface of the entire Kîlauea Volcano has been covered by lava. In addition, the LERZ area around $\mathrm{Pu}$ 'uhonua'ula and $\mathrm{Pu}$ 'ulena Crater experienced a series of explosive events between 500 and 1,300 years ago leaving tephra deposits as thick as $20 \mathrm{~m}$ (65 ft) over an area of $4 \mathrm{~km}^{2}$ (1,000 acres).

The 2018 eruption does not seem to be unusual considering the frequency of LERZ eruptions, but the eruption rate was high compared to the range documented for Killauea Volcano over the

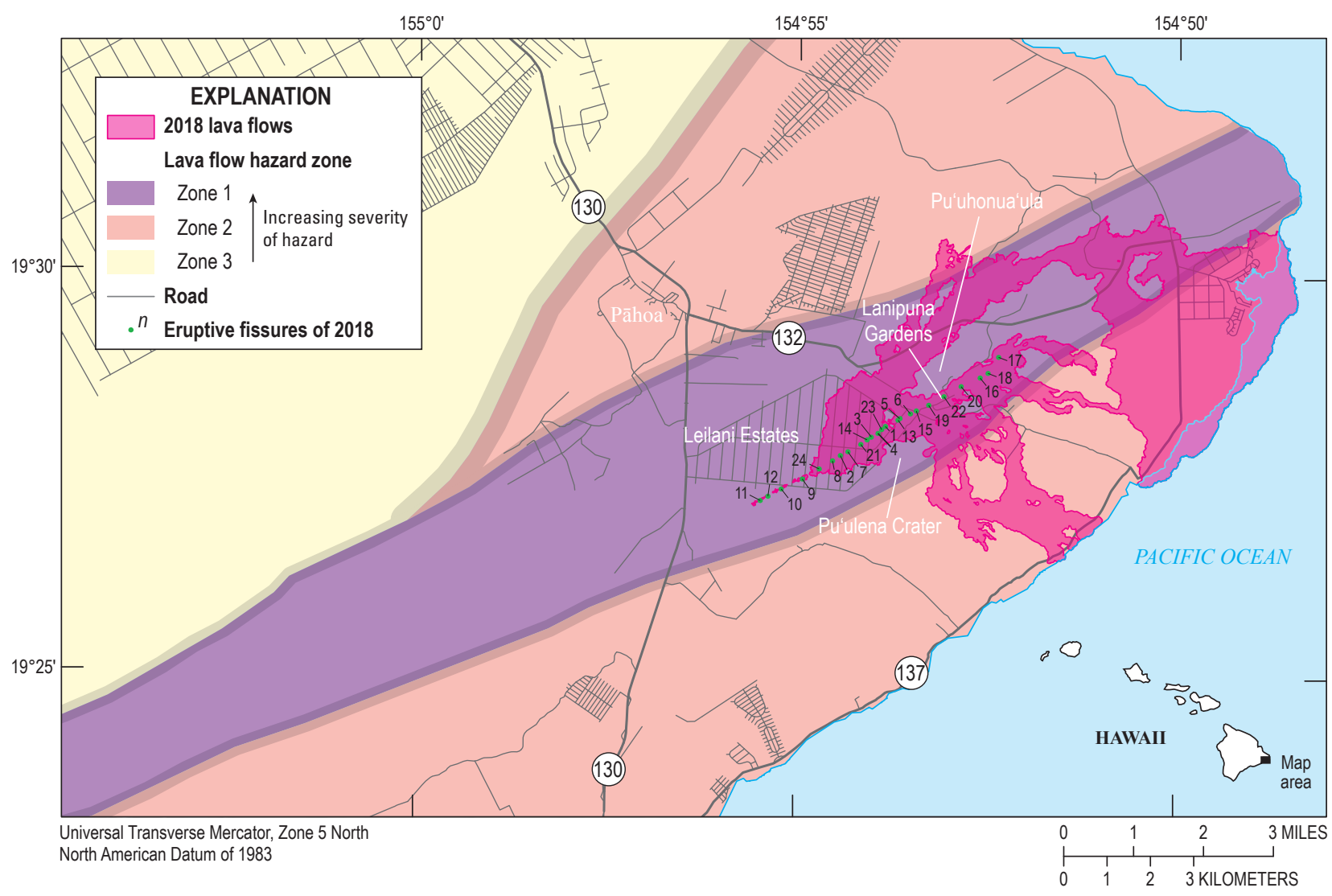

Figure 4. Map showing the 2018 lava flows (pink) plotted over the lava flow hazard zone map of Wright and others (1992). The numbered dots along the rift zone are the 24 fissures that erupted in 2018 numbered in chronological order. 
past 250 years. The 2018 erupted volume and eruption rate were the most accurate such calculations, and it would be difficult to compare directly to the volume calculations for previous eruptions. Without knowledge of the pre-eruption topography for the 1790 or 1840 eruption, their volumes were calculated by estimating an average thickness from the height of the flow edges and multiplying by the area. Therefore, the estimated volumes for the 1790 and the 1840 flow are minimums.

The 2018 Kîlauea eruption rate was most similar to past Mauna Loa eruption rates (Patrick and others, 2019) and was twice the minimum rate estimated for the 1840 LERZ eruption. The actual eruption rate for the 1840 was probably closer to the 2018 eruption rate than it appears if one takes into account the uncertainties in the volume calculation mentioned in the previous paragraph.

Nevertheless, the magma that was erupted in the lower East Rift Zone in 2018 originated in the summit and middle East Rift Zone. Additional factors in the source regions (summit and middle East Rift Zone) affecting the availability of a large volume of magma could include the 2001-06 surge in magma supply from the mantle and the low eruption rates during later years that may have resulted in more magma storage beneath the summit and $\mathrm{Pu}^{\prime} \mathrm{u}$ ' $\overline{\mathrm{O}}^{‘} \bar{o}$ (Anderson and Poland, 2016). Once the $\mathrm{Pu}^{\prime} \mathrm{u}$ ' $\overline{\mathrm{O}}^{`} \overline{\mathrm{o}}$ vent shut down, the increase in magma storage may have provided a large reservoir to augment the intrusion into the lower East Rift Zone.

The average repose interval between the six LERZ eruptions in the past 250 years (1790-2018) is 46 years which is not significantly different than the 42.75 -year repose interval calculated by Moore (1992) for the interval 1790-1961 and is consistent with the 60-65 percent probability of lava inundation in any 50-year period for the geothermal subzones estimated by Kauahikaua and others (1994).

Many LERZ eruptions involved multiple fissure vents. All were within and parallel to the East Rift Zone. Both the 1955 and the 2018 eruption involved more than 20 fissure vents and started in the vicinity of the hydrothermal area between $\mathrm{Pu}$ 'uhonua'ula and $\mathrm{Pu}$ 'ulena Crater.

Lava from the 2018 eruption issued from fissures within lava flow hazard zone 1 of Wright and others (1992) and flowed within lava flow hazard zones 1 and 2 demonstrating that the lava flow hazard zone map, based on vents and lava flow coverages over the past several centuries, was a good tool for forecasting the location of future volcanic activity.

The increased possibility of an eruption in the LERZ immediately following the end of the $\mathrm{Pu}^{\prime} \mathrm{u} u$ ' $\overline{\mathrm{O}}^{`} \mathrm{o}$ eruption was also forecast in Moore's (1992, p. 475) summary of LERZ geology:

The most recent eruption occurred in 1961, and the area may be overdue for its next eruption. However, eruptive activity will not resume on the LERZ until either the dike feeding the current eruption on the middle east rift zone extends farther down rift, or a new dike, unrelated to the current eruption, extends into the LERZ.

\section{Geophysical Expressions of the Kîlauea LERZ}

Whereas geologic studies detail surface expressions of volcanic structure and activity, geophysical studies are usually enlisted to provide information about subsurface structures. Measurements of gravity and magnetic field variations can be used to interpret subsurface distributions of density and magnetization, respectively. Each of these properties can be used to infer subsurface rock type and structure. Hawaiian rocks cannot hold magnetization at temperatures above the Curie temperature of $540{ }^{\circ} \mathrm{C}$ (Zablocki, 1977), so the data can also be used to detect regions of very high temperature rocks.

Using data collected during overflights in 1978, Flanigan and Long (1987) were able to image the denser, more magnetized dikes that make up the East Rift Zone of Kîlauea Volcano:

The most prominent magnetic feature ... is associated with the east rift of Kilauea [sic] Volcano and consists of linear dipole anomalies, of nearly 2,000-nT amplitude, extending eastward from the summit of Kilauea [sic] to within $7 \mathrm{~km}$ of the coast, where the dipole anomaly abruptly terminates as a linear feature. East of this termination point, several individual magnetic highs and lows characterize the magnetic expression of the rift zone (Flanigan and Long, 1987, p. 938).

Seismic refraction and gravity mapping showed "a complex of dikes containing solidified magma from past volcanic eruptions that provide energy for the hydrothermal processes associated with the rift zone" (Broyles and others, 1979).

Within the East Rift Zone dike structure built over millennia of volcanic activity, more recent subsurface activity suggested that the LERZ was not uniformly active throughout the Puna District and a center of activity was identified through several different types of studies. Zablocki (1977, p. 177) mapped the electrical potentials in the LERZ as a method of locating subsurface hydrothermal reservoirs:

Self-potential (SP) studies made in the area of Kilauea [sic] volcano's lower east rift zone (East Puna) delineated four positive-potential anomalies that are most likely related to magma or hot intrusions at depth. Previous and concurrent SP studies in Kilauea's [sic] summit area showed that similar types of anomalies can be related unambiguously to such localizations of heat.

Three of the anomalies mapped in East Puna are elongate parallel to the rift zone. One of these, just north of Puulena [sic] crater, is associated with a small-amplitude linear anomaly whose axis is transverse $\left(\mathrm{N} 47^{\circ} \mathrm{W}\right)$ to the trend of the rift zone. The transverse feature is located where there appears to be an areal offset (left lateral) in the rift zone and is coincident with the epicentral area of recurrent, shallow $(\sim 4 \mathrm{~km})$ earthquake 
swarms in recent years. These factors, together with some hydrologic and geologic inferences, collectively suggest that the SP features in this area reflect permeable, vertical fractures that have hot-water continuity with a relatively broad heat source at depth [emphasis added]. The results and conclusions derived from this study were instrumental in siting a test hole that was subsequently drilled as part of the University of Hawaii's geothermal program.

Flanigan and Long (1987, p. 940) also saw this feature in the airborne magnetic data:

A significant self-potential (SP) anomaly, aligned northwest, was attributed ... to permeable fractures that maintain fluid continuity with a heat source. Numerous warm springs along the downslope beaches and the occurrence of hot $\left(55^{\circ} \mathrm{C}\right)$ brackish water in wells in the conductive area... support the conclusion that the zone is related to a transverse structure that has offset the rift zone in a left-lateral sense. The linear dipole magnetic anomaly also has a left-lateral offset at this point. A small ( $300 \mathrm{nT})$ magnetic low, correlative with a resistivity low, is centered over the Puulenna [sic] Crater area, suggesting that ... heat source may still be above the Curie temperature.

These and other findings were used to site the exploratory geothermal well, HGP-A:

In early 1974 it was apparent that an exploratory drilling programme was essential to investigate the subsurface conditions predicted by the surveys. Consequently a Site Selection Committee was established in April 1974, chaired by Dr A. T. Abbot, to develop recommendations for the drilling programme and site selection. The committee considered all the geophysical, geological, thermal and geochemical evidence, and concluded that the most favourable site was on the Pahoa self-potential anomaly (Kingston Reynolds Thom \& Allardice Limited, 1976, p. 1).

Later studies sought to define the subsurface hydrothermal system tapped by HGP-A. Early in 1993, Cooper and Dustman (1995) set out an array of 24 seismometers centered around one of the Puna Geothermal Venture wells. The array operated for three months before the geothermal well went into operation:

In three dimensions, we can approximate the shape of the low $\mathrm{Vp} / \mathrm{Vs}$ anomaly as an oblate spheroid, centered between Pu'u Honuaulua [sic; Pu 'uhonua'ula] and Pu'ulena Crater at a depth of $2 \mathrm{~km}$. The total dimensions of the anomaly are $2.5 \times 2 \times 1.5 \mathrm{~km} . \mathrm{Vp} / \mathrm{Vs}$ reached a minimum of 1.66 in contrast to the background value of 1.78. Structures deeper than $4 \mathrm{~km}$ were not imaged well due to the reduced ray density (fewer observations) below $4 \mathrm{~km}$ (Cooper and Dustman, 1995, p. 73).
The region of low $\mathrm{Vp} / \mathrm{Vs}$ at Puna also correlates well with the self-potential and resistivity highs previously used to identify the lateral extent of the reservoir ...

Geothermal reservoirs with temperatures and pressures high enough to sustain steam-dominated systems are associated (usually) with low $\mathrm{Vp} / \mathrm{Vs}$ values. This occurs because P-wave velocities are substantially slowed by the presence of steam-filled cracks while shear velocities remain less affected ... In contrast, partially molten bodies exhibit high $\mathrm{Vp} / \mathrm{Vs}$ values ... The physical properties most affecting the $\mathrm{Vp} / \mathrm{Vs}$ ratio are the sizes, aspect ratios, and distributions of cracks and pores (Cooper and Dustman, 1995, p. 102).

\section{Summary}

Magnetic and gravity data define a linear subsurface mass of dense magnetic material within the East Rift Zone, consistent with surface features indicating multiple dike intrusions, that extends from Kîlauea Summit to Pu'uhonua'ula. The geophysical signature is offset to the north there and weakens to the east. The geophysical rift zone is $2-3 \mathrm{~km}$ wide. The self-potential map (Zablocki, 1977) suggested the presence of a subsurface hydrothermal reservoir later targeted for geothermal energy development by the University of Hawai' $i$ and Puna Geothermal Venture. Later mapping of seismic Vp/Vs ratios (the ratio of compressional wave to shear wave velocity) by Cooper and Dustman, 1995) provided approximate dimensions and a depth of $2 \mathrm{~km}(1.2 \mathrm{mi})$ of the reservoir in the vicinity of $\mathrm{Pu}^{\prime}$ 'uhonua'ula and $\mathrm{Pu}$ 'ulena Crater.

\section{Earthquakes in the Kîlauea LERZ}

There have been concerns expressed about whether development of the hydrothermal resource in the LERZ generates earthquakes. Some have suggested that the reinjection of geothermal fluids by Puna Geothermal Venture produced increased seismicity in nearby areas (see Big Island Video News, 2019). But as long as seismic networks have operated in the Puna District, beginning years before any geothermal production or reinjection wells were operational, earthquakes have been recorded frequently in the LERZ:

... rift zone orientations are dictated by gravitational stresses, and along with Zablocki, we propose that the offset of eruptive features near Puulena and Puu Honuaula [sic] represents a structural disruption in the east rift where magma tends to accumulate and where changes in the stress pattern takes place. The seismic swarms could represent incremental southeastward displacements of the rift zone west of Puu Honuaula [sic] accompanied by the shifting of the stored magma there. The small earthquakes 
appear to initiate near Puu Honuaula [sic] and typically occur in swarms, whereas many moderate events that follow extend farther and deeper into the unstable south flank ... In summary, the intensity and frequency of microearthquake swarms at Puu Honuaula [sic] are dictated by the state of instability of the structure caused by (1) refilling of magma from renewed intrusive activity there, (2) stresses generated from repeated magmatic activity along Kilauea's [sic] upper flanks, and (3) from constant gravitational loading due to Mauna Loa buttressing from the northwest (Koyanagi and others, 1981, p. 12).

The seismic array, installed in 1993 and operated for three months before Puna Geothermal Venture operations began, recorded frequent earthquakes in the area:

The background seismicity rate for the Puna geothermal region is about 8 earthquakes per day ... Magnitudes vary from -1.0 to 2.0 ; earthquakes with magnitudes greater than 2.0 occur at an historical rate of 4-10 per year (averaged over 1987-1992). That rate is by no means constant; earthquakes typically occur as multiplets, i.e. 2-10 small-magnitude earthquakes with similar wave forms within a period of 2-20 minutes, and as swarms lasting for several hours.

Cooper and Dustman (1995, p. 103) state: ... No significant change in the background seismicity rate was observed during the 5 days after KS-9/10 was brought to full production levels. (A single seismometer left running at the Puna Research Center from August 1994 to June 1995 also detected no significant change in background seismicity).

About 6,000 events were recorded by an 8-seismometer borehole network centered on the Puna Geothermal Venture operation during the years 2006-09 (Kenedi and others, 2010). Figure 4 of Kenedi and others (2010) shows loa log-log graph of 3,320 earthquakes plotted versus magnitude, with about 2,900 estimated at magnitude $(M) 0.5$ or weaker (fig. 5).

Seismicity occurs in a northeast-trending linear swath consistent with the orientation of the Kilauea [sic] Lower East Rift Zone. The majority occurs under the geothermal plant, at depths from 1.5 to $3.5 \mathrm{~km}$; this is consistent with geothermal production and injection at these depths. Earthquakes at depths of 3.5-5.5 km occur throughout the system but are most visible up-rift towards Kilauea [sic] summit. Earthquakes of increasing depth occur to the southeast of the rift; this is consistent with the presence of a large normal fault of northeasterly strike and southeasterly dip. Such a fault has been suggested in field mapping but not described in detail; the presence of the fault would be consistent with the southerly movement of the south flank of Kilauea [sic] along the dominant plane underlying the Hilina Fault System (Kenedi and others, 2010, p. 2-3).
In analyzing the data presented in her figure 4 , Dr. Kenedi performed statistical analysis on the data for all earthquakes detected during the 3-year study: "The increase in slope at magnitude below 0.5 indicates that there is an increase in the number of events smaller than M0.5; 95\% are of magnitude $<0.5$. This may be attributed to reinjection of geothermal fluid [italics mine]." The log-log histogram of number of earthquakes versus magnitude is generally linear with fewer earthquakes of stronger magnitude with increasingly more earthquakes at weaker magnitudes. Dr. Kenedi is not referring to all $M 0.5$ or weaker earthquakes, only the slight increase in that number of magnitude- 0.5 or smaller earthquakes over the line plotted in figure 4 of Kenedi and others (2010).

\section{Summary}

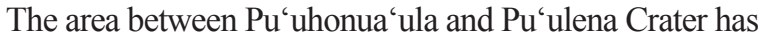
been a center of earthquake activity since $\mathrm{HVO}$ began monitoring seismicity in 1960. Recent studies focused on the hydrothermal reservoir tapped by Puna Geothermal Venture confirm that it is still a focus of seismicity. Cooper and Dustman (1995) concluded that geothermal operations did not increase the seismicity of the area in 1993 when operations began, whereas Kenedi and others (2010) concluded that there was a few percent increase over background in the number of earthquakes weaker than magnitude 0.5 over a linear trend (number of earthquakes increasing exponentially with decreasing magnitude) during the period 2006-09.

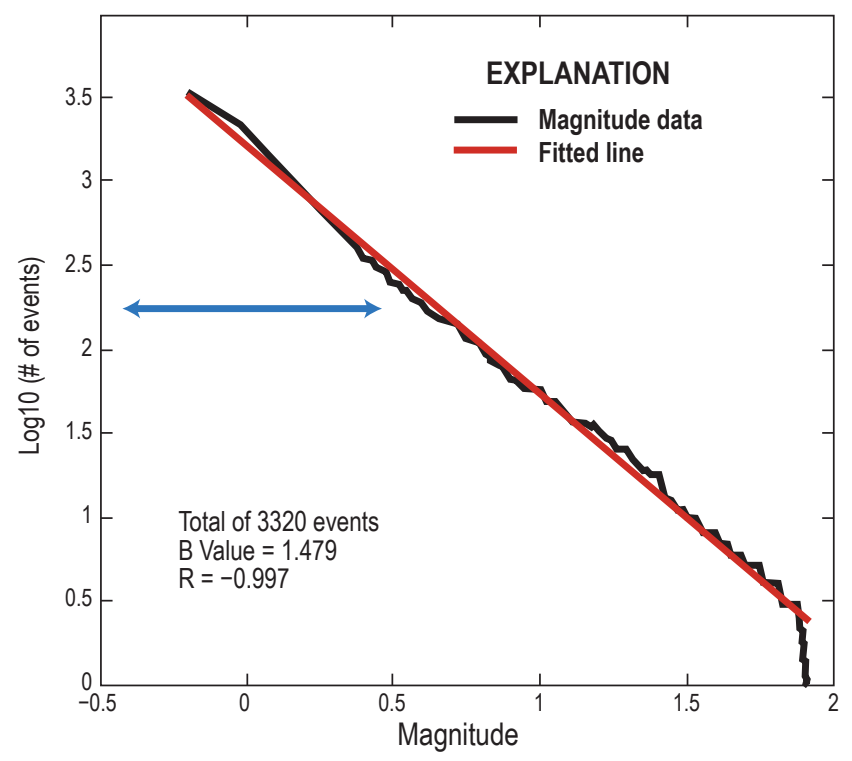

Figure 5. Plot of earthquake occurrence of a given magnitude according to the Gutenberg-Richter relation, modified from figure 4 of Kenedi and others (2010). The blue double-headed arrow shows the range where increased numbers of earthquakes with magnitudes less than 0.5 have been recorded. The red line represents the anticipated/projected background seismicity and the black line is the actual number of events. In the range of magnitudes denoted by the blue arrow, the actual number of events is slightly greater than background. 
A second source of earthquakes identified by each of these studies was a south-dipping fault that was parallel with and on the southern edge of the East Rift Zone. Figure 6 is a map of the LERZ showing the contoured electric-potential data (Zablocki, 1977) plotted with the epicenters from Cooper and Dustman (1995) and Kenedi and others (2010).

The only significant seismicity observed in the area is consistent with natural sources - the subsurface hydrothermal system and the rift zone fault to the south.

\section{Ground Deformation in the Kïlauea LERZ}

Two episodes of significant subsidence have been observed in the LERZ of Kîlauea Volcano in 1868 and 1924.

Delaney and others (1998) described long-term subsidence of the entire East Rift Zone of Killauea Volcano after the 1975 M7.7 south flank earthquake:

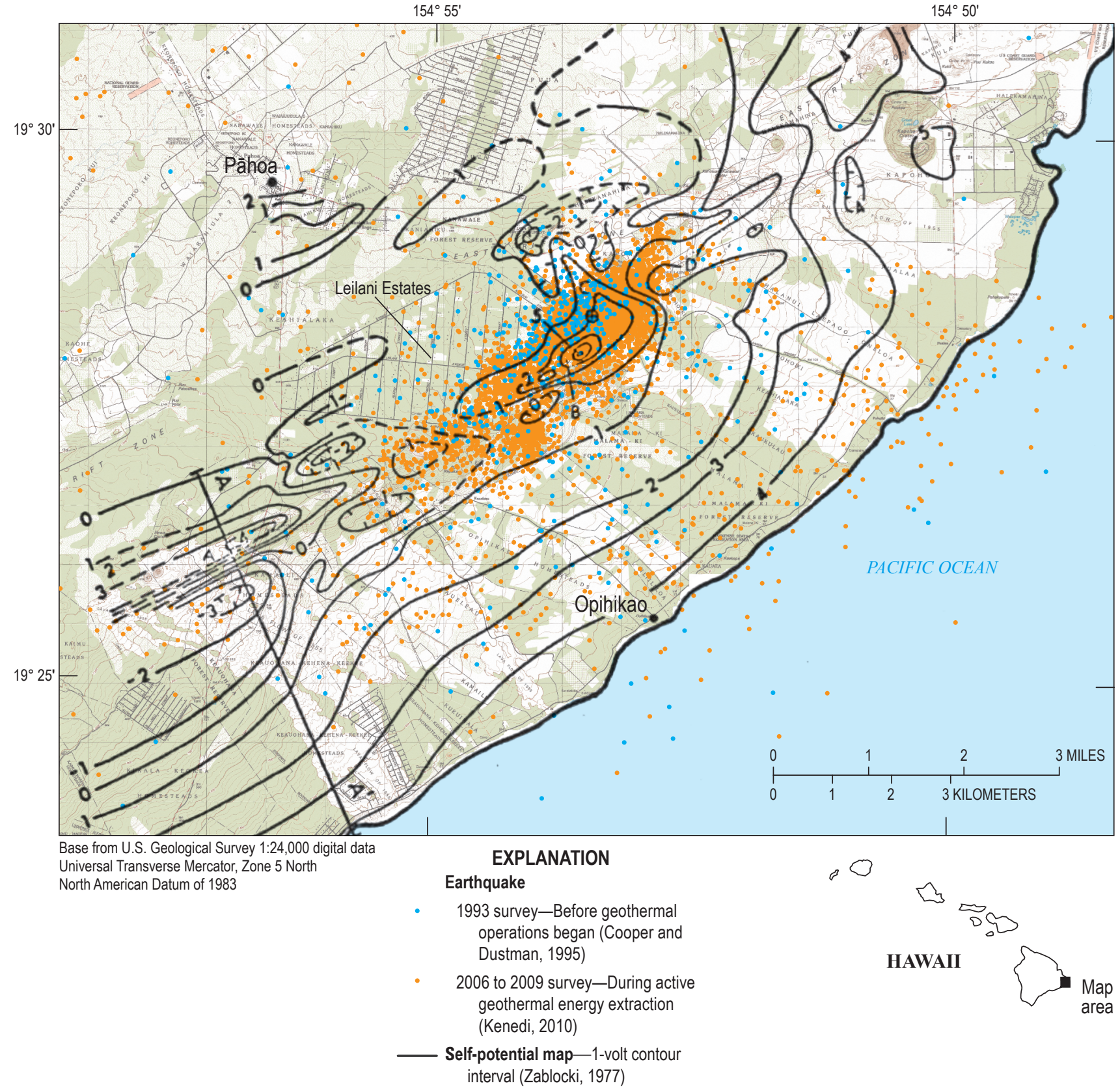

Figure 6. Map showing the locations of earthquakes detected during two important seismic surveys on the lower East Rift Zone of Killauea Volcano: the 3-month 1993 survey before geothermal operations began (blue dots; Cooper and Dustman, 1995) and the 4-year 2006-09 survey during active geothermal energy extraction (orange dots; Kenedi and others, 2010). The earthquakes are plotted over the self-potential map (black contours, 1-volt interval; Zablocki, 1977). Earthquakes both before and during geothermal development plot within the self-potential high that has been interpreted as a subsurface hydrothermal resource. 
The ground surface at two water wells ... situated $7.1 \mathrm{~km}$ apart along the lower east rift zone, has been subsiding since 1976 at average rates of 1.4 and 1.7 cmyr $^{-1}$, respectively ... Rates of subsidence along the lower east rift zone determined from water well data are confirmed by leveling from the Hilo tidal network ... From Kapoho, bench marks 166YY and $\mathrm{HVO} 3$ are $0.4 \mathrm{~km}$ away along the $65^{\circ}$ azimuth of the rift zone and $1.3 \mathrm{~km}$ away to the north, respectively. These benchmarks have subsided 1.4 and $1.5 \mathrm{cmyr}^{-1}$, respectively, the latter in the position of maximum subsidence (Delaney and others, 1998, p. 18,010).

Hwang (2007) recently documented continuing subsidence in the Kapoho area:

Using Synthetic Aperture Radar Interferometry (InSAR) techniques and radar data from the European Space Agency's Envisat, an estimate for subsidence at Kapoho could be determined for the period from February 12, 2003 to March 8, 2006 . . . From the InSAR study, the immediate Kapoho region experienced average downward vertical motions, with respect to Hilo of between $\sim-\mathbf{0 . 7}$ and $-1.6 \mathrm{~cm} / \mathrm{yr}+/-0.6 \mathrm{~cm} / \mathrm{yr}$. The $0.6 \mathrm{~cm} / \mathrm{yr}$. represents 2 standard deviations [emphasis added]. Combined with the rising sea levels measured in
Hilo and believed to be representative for Kapoho, the relative sea level rise for Kapoho has thus been estimated to be $\sim 0.8$ to $1.7 \mathrm{~cm} / \mathrm{yr}+/-0.8 \mathrm{~cm} / \mathrm{yr}$ (2 standard deviations) (Hwang, 2007, p. 9).

HVO installed a GPS instrument at monument WAPM, just north of Pu'uhonua'ula, on the Puna Geothermal Venture property in 2004. For reference, the company's operations include reinjection that started in April of 1993 (Mike Kaleikini, 2019, written commun.). The volume rate of fluid injection of geothermal fluids averaged about $8 \times 10^{6} \mathrm{~m}^{3} / \mathrm{yr}\left(1.8 \times 10^{9} \mathrm{gal} / \mathrm{yr}\right)$.

The motion of the WAPM monument (fig. 7) was quite steady to the southeast and down from installation in 2004 to early 2018 before the eruption. This type of ground motion is consistent with East Rift Zone subsidence measured at other locations (Delaney and others, 1998; Hwang, 2007). If the injection of fluids at depths of $2.4 \mathrm{~km}$ (1.5 mi) were significantly pressurizing that area, the ground surface at WAPM would be moving in the exact opposite direction - northwest and up.

After the collapse of $\mathrm{Pu}^{\prime} \mathrm{u}$ ' $\overline{\mathrm{O}}^{`} \mathrm{o}$ on April 30, 2018, a dike of molten magma was injected below the surface from $\mathrm{Pu}^{`} \mathrm{u}{ }^{`} \overline{\mathrm{O}}^{`} \overline{\mathrm{o}}$ into the lower East Rift Zone, which fed the eruption that started on May 3. When the dike passed near the WAPM location, the ground surface reversed its slow southeast and down motion and rapidly moved northwest and up as we would expect for deep pressurization of the rift zone (Neal and others, 2018).
Figure 7. Plots of movement of the Global Positioning System monument WAPM from installation in 2004 to removal in May 2018. The data show steady, regular motion to the southeast and down until a nearby dike intrusion in early May caused rapid movement northwest and up.

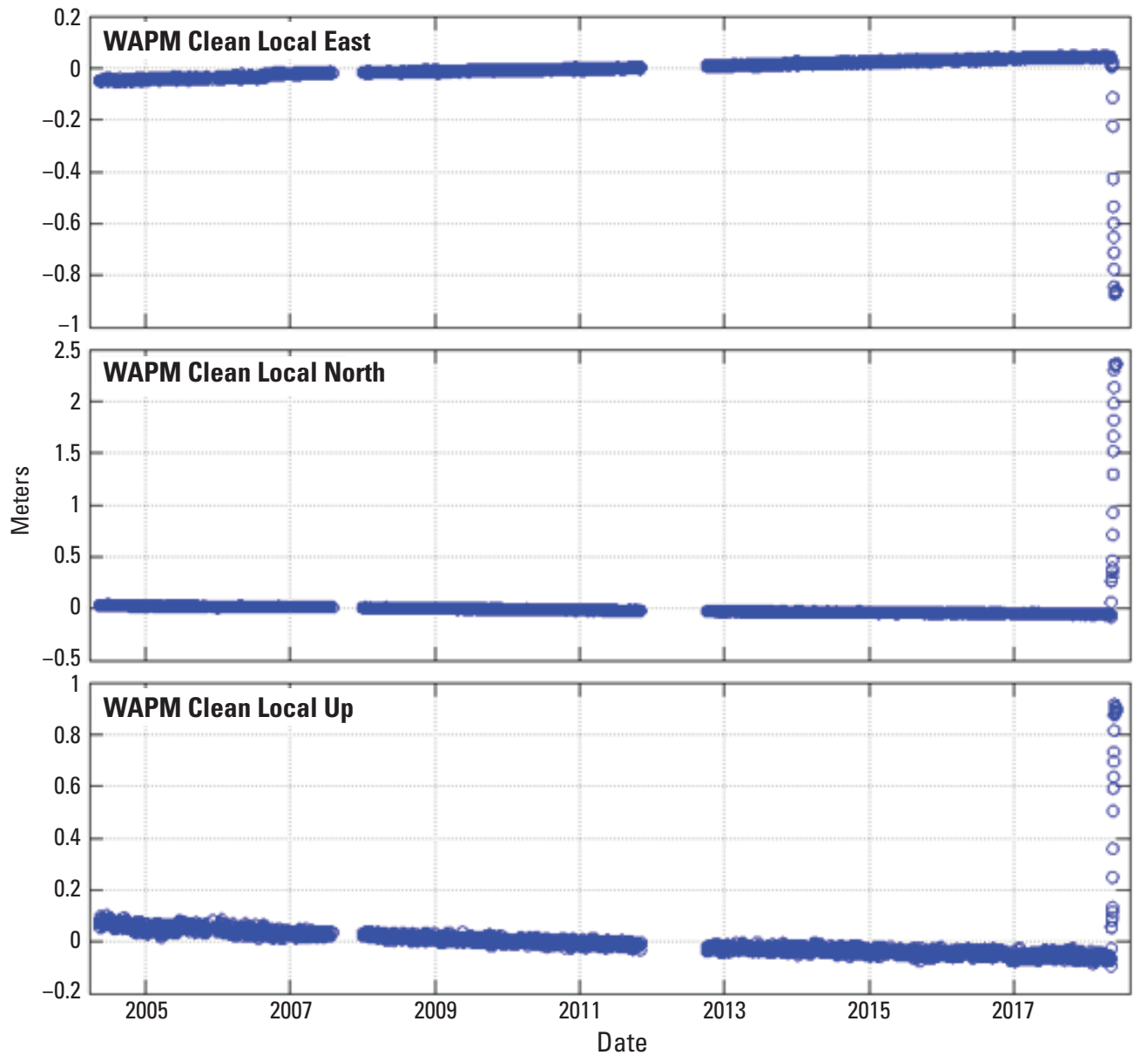




\section{Summary}

The LERZ has been subsiding at rates of about $1 \mathrm{~cm} / \mathrm{yr}$ ( $0.4 \mathrm{in} / \mathrm{yr}$ ) since the 1975 South Flank earthquake. The only change noted was in response to the dike injection from $\mathrm{Pu}^{\mathrm{u}} \mathrm{u}$ ' $\bar{O}^{`} \bar{o}$ to the LERZ in 2018 that resulted in an eruption. There was no evidence of a significant pressure increase at depth near the WAPM monument in the LERZ before the 2018 dike injection.

\section{Groundwater Studies in the Kilauea LERZ}

In the 1990s, questions about the nature of groundwater within Kîlauea Volcano and its response to frequent eruptions were investigated using a number of methods. For a broad overview of links between rainfall recharge and groundwater, Scholl and others (1995) determined the relation between rainfall elevation and stable isotopes so that they could be matched with similar isotopes in groundwater:

Areal contrasts in ground-water stable isotopes and tritium indicate that the volcanic rift zones compartmentalize the regional ground-water system. Tritium levels in ground water within and downgradient of Kilauea's [sic] rift zones indicate relatively long residence times (Scholl and others, 1995, p. 1).

The easternmost springs in this area are located such that both storm and trade wind rainfall probably contribute to recharge. Their recharge elevation was calculated assuming that half the recharge comes from storms and half from trade wind rains. On this basis, recharge elevations for those two springs are also no higher than the rift zone. Wells and springs south of the ERZ ... had more enriched isotopic composition than those further [sic] west, and recharge elevation was calculated using the trade wind relation. Isotopic composition for these springs and wells also indicates that they are recharged locally (Scholl and others, 1995, p. 27-28).

The warm springs downgradient from the lower ERZ do not contain thermal fluids like those found in the deep geothermal wells in the rift zone. Rather, their chemistry is that of diluted seawater except for silica and bicarbonate levels, and silica and chloride content increase with increasing temperature. A plausible explanation for the spring chemistry is that seawater in saturated rock below the freshwater lens south of the lower ERZ is heated to about $165^{\circ} \mathrm{C}$, boils to $100^{\circ} \mathrm{C}$ and loses steam, and then mixes with the overlying freshwater lens and flows toward the shoreline, where it is further mixed with seawater from the ocean as it discharges (Scholl and others, 1995, p. 31).
Stable isotopes from the shallow wells and thermal springs in the lower ERZ showed no evidence for down-rift flow. Therefore, elevated ${ }^{3} \mathrm{H}$ levels in the lower ERZ shallow ground water suggest low permeabilities, rather than a long flowpath (Scholl, 1995, p. 33).

Coincident with Scholl and others (1995), extensive groundwater sampling was done that provided the baseline measurements for repeat analysis in 2015 (Evans and others, 2015):

We report chemical data for selected shallow wells and coastal springs that were sampled in 2014 to determine whether geothermal power production in the Puna area over the past two decades has affected the characteristics of regional groundwater. The samples were analyzed for major and minor chemical species, trace metals of environmental concern, stable isotopes of water, and two organic compounds (pentane and isopropanol) that are injected into the deep geothermal reservoir at the power plant. Isopropanol was not detected in any of the groundwaters; confirmed detection of pentane was restricted to one monitoring well near the power plant at a low concentration not indicative of source. Thus, neither organic compound linked geothermal operations to groundwater contamination, though chemical stability and transport velocity questions exist for both tracers. Based on our chemical analysis of geothermal fluid at the power plant and on many similar results from commercially analyzed samples, we could not show that geothermal constituents in the groundwaters we sampled came from the commercially developed reservoir [emphasis added]. Our data are consistent with a long-held view that heat moves by conduction from the geothermal reservoir into shallow groundwaters through a zone of low permeability rock that blocks passage of geothermal water. The data do not rule out all impacts of geothermal production on groundwater. Removal of heat during production, for example, may be responsible for minor changes that have occurred in some groundwater over time, such as the decline in temperature of one monitoring well near the power plant. Such indirect impacts are much harder to assess, but point out the need for an ongoing groundwater monitoring program that should include the coastal springs down-gradient from the power plant (Evans and others, 2015, p. 1).

Unlike pentane, isopropanol is quite soluble in water, so that partitioning into gas bubbles during sample collection at ambient temperature is not a significant concern. At high temperatures, volatility does become important, and most of the injected isopropanol that survives transport through the 
reservoir to the production well partitions into the steam line. The isopropanol concentration in PG14$14 \mathrm{~S}$ was $60.5 \mathrm{mg} / \mathrm{L}$; that in PG14-14B was $3.8 \mathrm{mg} / \mathrm{L}$. Interestingly, the ratio of isopropanol concentration in injectate to that in steam is $8.2: 1$, not too different from the pentane ratio for injectate to steam, which is $6.4: 1$ based on the average pentane concentration in the two steam samples in table 5. Either the two compounds degrade at comparable rates in the reservoir, or they degrade very little and the concentration ratios reflect the reservoir dilution factor. Isopropanol was below detection $(<0.8 \mathrm{mg} / \mathrm{L})$ in all samples, except for the three collected from the plant, and thus provided no evidence for PGV-derived fluid in the groundwaters [emphasis added] (Evans and others, 2015, p. 12).

As Hawaii populations grew, pollution of the shallow groundwater by cesspools and by agricultural effluent became a concern (Raine, 2019). A statewide ban on new cesspool construction was signed into law in 2016, but a plan for mitigating the effects of the existing cesspools has yet to be realized. The Hawaii State Department of Health has identified 14 priority areas in the state where cesspool upgrades are critical and two of these are in Puna-Kea'au and Kapoho (Big Island Now, 2017). Only the Kapoho priority area is in the lower East Rift Zone area.

Several studies have focused on the quality of groundwater seeping into the Waiopae tidepools south of Kapoho Bay (Division of Aquatic Resources, 2019). The area, made a Marine Life Conservation District in 2003, was located immediately offshore of the Vacationland subdivision whose residences were serviced by cesspools. Concerns were raised about untreated sewage flowing into Waiopae tide pools from those cesspools. In 2004, a Hawaii District Science Fair project studied the water quality at the tide pools and found that "the pools closer to the open ocean had the lowest coliform content, while some nearest shore had the highest. These levels were higher than allowed for safe drinking water but lower than the allowed levels for swimming" (Volcano Watch, 2004). Wiegner and others (2016) analyzed sources of nitrogen in Kapoho thermal tide pools and found that 61 percent of the nitrogen was anthropogenic--34 percent from agriculture soil and 27 percent from sewage.

\section{Summary}

The geothermal reservoir is not connected to shallow groundwater. Evans and others (2015) could not show that geothermal constituents of shallow groundwater came from the commercially developed hydrothermal reservoir. Their study did show that one of the chemical tracers (isopropanol) dispersed from the deep injection wells to the shallower production wells within a few months suggesting significant permeability within the hydrothermal system.

The shallow groundwater that is tapped for domestic water uses has been significantly affected by human population as shown in the Kapoho area. Agriculture and raw sewage from prevalent use of cesspools are the primary pollutants.

\section{Conclusions}

There are no obvious effects of human activity on eruptions of Kîlauea volcano. There have been no significant changes due to human activity in patterns or trends of deformation or seismicity in the lower East Rift Zone in the last 35-50 years (before and during geothermal operations). The frequency and intensity of eruptions are variable, but it would be difficult to demonstrate a definitive change due to human activity. Contamination of shallow ground water by geothermal fluids is not evident; however, increased residential or agricultural activity has contaminated the shallow groundwater and, by coastal seeps, the nearshore seawater. There is also evidence that the water from at least one well south of the rift zone was rendered brackish and unusable after the eruption.

Volcanic hazards in the lower East Rift Zone of Kîlauea Volcano have always been significant. The lava flow hazard map (Wright and others, 1992), the result of extensive geologic mapping and lava flow dating, makes that clear by denoting most of the lower East Rift Zone and adjacent area at the highest rating of hazard zones 1 and 2; however, as the population continues to grow and more land is converted to residential, the risk increases proportionally. The Pacific Disaster Center recently completed a volcanic multi-hazard risk assessment for the Island of Hawai' $i$ which concluded that lower Puna District (census tract 1 and 2) had the highest exposure on the island (Green and others, 2019).

A geothermal development, located within the area of the lower East Rift Zone has been producing electric power for the local electric power utility since it began operations in 1993; in 2018, the development was producing about a quarter of the island's energy supply (Public Utilities Commission, 2018) before it was shut down by the 2018 eruption. Since the 2018 eruption, whether development not only caused the eruption, but also caused an unusually high eruption rate, and caused the eruption to occur in this area, has been the subject of public discussion.

We find no evidence to support claims that human activity triggered or influenced the 2018 lower East Rift Zone eruption. The 2018 eruption was caused by injection of magma downrift from $\mathrm{Pu}^{\prime} \mathrm{u}$ ' $\overline{\mathrm{O}}^{`}$ ō and the summit of Kîlauea. The event fits a pattern of activity that has occurred many times previously on the East Rift Zone and is within the range of normal behavior for Killauea Volcano. The 2018 eruption happened within hazard zone 1 (Wright and others, 1992) and the erupted lava flowed through that zone into lava flow hazard zone 2 (fig. 3). The spectacular intensity of the eruption - its high volume and high eruption rate-were probably not out of the range estimated for previous lower East Rift Zone eruptions given the uncertainties in the volume calculation errors for the earlier eruptions. Finally, the 2018 fissures were located in the same area that has hosted many past eruptions. 


\section{Acknowledgments}

The authors wish to acknowledge very helpful review comments by Matt Patrick, Janet Babb, Tina Neal, Brian Shiro, Ingrid Johanson, Jefferson Chang, Bill Evans, and Tom Murray of the USGS. and Philip Nigri of the Hawaii State Department of Land and Natural Resources, Engineering Division. Editorial reviews, as well as layout choices by Claire Landowski, Phil Frederick, and JoJo Mangano of the USGS Menlo Park Publications Service Center further improved this publication.

\section{References}

Anderson, K.R., and Poland, M.P., 2016, Bayesian estimation of magma supply, storage, and eruption rates using a multiphysical volcano model: Kîlauea Volcano, 2000-2012: Earth and Planetary Science Letters, v. 447, p. 161-171, available at https://doi.org/10.1016/j.epsl.2016.04.029.

Big Island Now, 2017, 5 of 14 Cesspool Priority Areas are on Big Island, available at https://bigislandnow.com/2017/12/20/5-of14-cesspool-priority-areas-are-on-big-island.

Big Island Video News, 2019, Geothermal Questions Answered by USGS ahead of Community Meeting, accessed on December 20, 2019, at https://www.bigislandvideonews. com/2019/03/21/geothermal-questions-answered-by-usgsahead-of-community-meeting/

Broyles, M., Suyenaga, W., and Furumoto, A., 1979, Structure of the lower East Rift Zone of Kilauea Volcano, Hawaii, from seismic and gravity data: Journal of Volcanology and Geothermal Research, v. 5, p. 317-336, available at https://doi. org/10.1016/0377-0273(79)90022-2.

Coan, T, 1840, Letter from Mr. Coan dated at Hilo, 25th Sept. 1840: The Missionary Herald, v. XXXVII, No. 7, p. 283-285.

Cooper, P. and Dustman, M., 1995, Geothermal Research, Monitoring and Testing-Final Report, Geophysics Subtask, Microseismicity Study, unpublished report available at https://scholarspace.manoa.hawaii.edu/ handle/10125/63531.

Dana, James D., 1849, United States Exploring Expedition during the years 1838, 1839, 1840, 1841, 1842 under the command of Charles Wilkes, U.S.N-Geology: New York, Geo. P. Putnam, v. 10, 756 p., available at https://doi. org/10.5962/bhl.title.69333.

Delaney, P.T., Denlinger, R.P., Lisowski, M., Miklius, A., Okubo, P.G., Okamura, A.T., and Sako, M.K., 1998, Volcanic Spreading at Kilauea, 1976-1996: Journal of Geophysical Research, v. 103, p. 18,003-18,023.
Division of Aquatic Resources, 2019, Hawai' $\mathrm{i}$-Wai`ōpae Tidepools: Department of Land and Natural Resources, available at https://dlnr.hawaii.gov/dar/marine-managed-areas/hawaiimarine-life-conservation-districts/hawaii-waiopae-tidepools/.

Dietterich, H., Patrick, M., Diefenbach, A., Lundgren, P., Cashman, K., and Grant, G., 2019, Lava effusion rates and channel dynamics during the 2018 Kîlauea lower East Rift Zone eruption: American Geophysical Union, poster V43C-0215.

Evans, W.C., Bergfeld, D., Sutton, A.J., Lee, R.C., and Lorenson, T.D., 2015, Groundwater chemistry in the vicinity of the Puna Geothermal Venture power plant, Hawai' $i$, after two decades of production: U.S. Geological Survey Scientific Investigations Report 2015-5139, 26 p., available at http://dx.doi.org/10.3133/ sir20155139.

Firozi, P., 2018, The Energy 202: Kilauea's eruption reignites debate over Hawaii's geothermal plant: The Washington Post, June 18, 2018, available at https://www.washingtonpost.com/ news/powerpost/paloma/the-energy-202/2018/06/18/the-energy202-kilauea-s-eruption-reignites-debate-over-hawaii-s-geothermal-plant/5b2652f21b326b3967989b27/?noredirect=on

Flanigan, V.J., and Long, C.L., 1987, Aeromagnetic and NearSurface Electrical Expression of the Kilauea and Mauna Loa Volcanic Rift Systems chap 39 of Decker, Robert W., Wright, Thomas L., Stauffer, Peter H., eds., 1987, Volcanism in Hawaii: U.S. Geological Survey Professional Paper 1350, p. 935-946, available at https://pubs.usgs.gov/pp/1987/1350/pdf/chapters/ pp1350_ch39.pdf

Green, J., Morath, D., Goering, C., Mielbrecht, S. Hughey, E., 2019, Kīlauea Eruption Risk Assessment 2018 Big Island, Hawai'i (ver. 1.0, 2019): Pacific Disaster Center, available at https://www.hawaiicounty.gov/home/showdocument?id=1729.

Hawaii County, 2019, Kỉlauea Eruption Recovery multimedia, available at https://recovery.hawaiicounty.gov/multimedia/ eruption-timeline

Hawaiian Volcano Observatory (HVO), 2019, Overview of Kỉlauea Volcano's 2018 lower East Rift Zone eruption and summit collapse: U.S. Geological Survey Hawaiian Volcano Observatory website, available at https://volcanoes.usgs.gov/ vsc/file_mngr/file-224/OVERVIEW_Kil2018_LERZ-Summit_ June\%202019.pdf

Heliker, C., 1990, Volcanic and seismic hazards on the Island of Hawaii: U.S. Geological Survey General Interest Publication, $48 \mathrm{p}$.

Holcomb, R., 1987, Eruptive history and long-term behavior of Kilauea Volcano chap. 12 of Decker, Robert W., Wright, Thomas L., Stauffer, Peter H., eds., Volcanism in Hawaii: U.S. Geological Survey Professional Paper 1350, 90 p., available at https:// pubs.usgs.gov/pp/1987/1350/pdf/chapters/pp1350_ch12.pdf 
Hwang, D.J., 2007, Coastal Subsidence in Kapoho, Puna, Island and State of Hawaii: Report prepared for Hawaii County Planning Department, 82 p., available at https://lnr.hawaii.gov/ occl/files/2013/08/Coastal-Subsidence-Final.pdf

Kauahikaua, J., Moore, R., and Delaney, P., 1994, Volcanic Activity and Ground Deformation Hazard Analysis for the Hawaii Geothermal Project Environmental Impact Statement, U.S. Geological Survey Open-File Report 94-553, 44 p. available at https://pubs.usgs.gov/of/1994/0553/report.pdf

Kenedi, C.L., Shalev, E., Lucas, A., and Malin, P., 2010, Microseismicity and 3-D Mapping of an Active Geothermal Field, Kilauea Lower East Rift Zone, Puna, Hawaii: Proceedings World Geothermal Congress 2010, 6 p., available at https:/www.geothermal-energy.org/pdf/IGAstandard/ WGC/2010/1352.pdf.

Kingston Reynolds Thom \& Allardice Limited, 1976, Hawaii Geothermal Project Well Completion Report HGP-A: University of Hawaii Research Corporation and U.S. Energy Research and Development Administration, 34 p., available at https://scholarspace.manoa.hawaii.edu/ bitstream/10125/21816/1/HGP_WellCompletionReport.pdf

Koyanagi, R.Y., Nakata, J.S., and Tanigawa, W.R., 1981, Seismicity of the lower east rift zone of Kilauea Volcano, Hawaii, 1960 to 1980, USGS Open-File Report 81-984, 28 p. available at https://pubs.usgs.gov/of/1981/0984/report.pdf.

Macdonald, G.A. and Abbott, A.T., 1970, Volcanoes in the Sea: The Geology of Hawaii, University of Hawaii Press, Honolulu, $441 \mathrm{p}$.

Macdonald, G.A. and Eaton, J.P., 1964, Hawaiian volcanoes during 1955: U.S. Geological Survey Bulletin 1171, available at https://pubs.er.usgs.gov/publication/b1171.

Mattox, T.N., Heliker, C., Kauahikaua, J., Hon, K., 1993, Development of the 1990 Kalapana Flow Field, Kilauea Volcano: Hawaii, Bulletin of Volcanology, v. 55, p. 407-413.

Monterey Bay Aquarium Research Institute (MBARI), 1998, MBARI Hawaii Multibeam Survey, available at https://www3. mbari.org/data/mapping/hawaii/

Moore, R.B., Helz, R.T., Dzurisin, D., Eaton, G.P., Koyanagi, R.Y., Lipman, P.W., Lockwood, J.P., and Puniwai, G.S., 1980, The 1977 Eruption of Kilauea Volcano, Hawaii: Journal of Volcanology and Geothermal Research, v. 7, p. 189-210.

Moore, R.B. 1992, Volcanic geology and eruption frequency, lower east rift zone of Kilauea volcano, Hawaii, Bulletin of Volcanology, v. 54, p. 475-483, available at https://doi. org/10.1007/BF00301393.

Moore, R.B., and Trusdell, F.A., 1991, Geologic map of the lower east rift zone of Kilauea Volcano, Hawaii: U.S. Geological Survey I-Map 2225, available at https://doi.org/10.3133/i2225.
National Oceanographic and Atmospheric Administration (NOAA), 2013, 2013 USACE Topobathy Lidar-Big Island (HI)-LMSL: NOAA website available at https://inport.nmfs. noaa.gov/inport/item/49744.

Neal, C.A., Brantley, S.R., Antolik, L., Babb, J.L., Burgess, M., Calles, K., Cappos, M., Chang, J.C., Conway, S., Desmither, L., Dotray, P., Elias, T., Fukunaga, P., Fuke, S., Johanson, I.A., Kamibayashi, K., Kauahikaua, J., Lee, R.L., Pekalib, S., Miklius, A., Million, W., Moniz, C.J., Nadeau, P.A., Okubo, P., Parcheta, C., Patrick, M.R., Shiro, B., Swanson, D.A., Tollett, W., Trusdell, F., Younger, E.F., Zoeller, M.H., MontgomeryBrown, E.K., Anderson, K.R., Poland, M.P., Ball, J.L., Bard, J., Coombs, M., Dietterich, H.R., Kern, C., Thelen, W.A., Cervelli, P.F., Orr, T., Houghton, B.F., Gansecki, C., Hazlett, R., Lundgren, P. Diefenbach, A.K., Lerner, A.H., Waite, G., Kelly, P., Clor, L., Werner, C., Mulliken, K., Fisher, G., and Damby, D., 2018, The 2018 rift eruption and summit collapse of Kīlauea Volcano: Science, v. 363, n. 6425, p. 367-374, available at https://doi.org/10.1126/science.aav7046.

Orr, T.R., 2018, GIS shapefiles for lava flows at Kilauea volcano, 1790-1982: U.S. Geological Survey data release, available at https://doi.org/10.5066/P9B7904I.

Patrick, M.R., Dietterich, H. R., Lyons, J. J., Diefenbach, A. K., Parcheta, C., Anderson, K. R., Namiki, A., Sumita, I., Shiro, B., and Kauahikaua, J. P., 2019, Cyclic lava effusion during the 2018 eruption of Kîlauea Volcano: Science, v. 355, no. 6470,10 p., available at https://doi.org/10.1126/science. aay 9070 .

Poland, M., Orr, T.R., Kauahikaua, J.P., Brantley, S.R., Babb, J.L., Patrick, M.R., Neal, C.A., Anderson, K.R., Antolik, L., Burgess, M., Elias, T., Fuke, S., Fukunaga, P., Johanson, I.A., Kagimoto, M., Kamibayashi, K., Lee, L., Miklius, A., Million, W., Moniz, C., Okubo, P.G., Sutton, A.J., Takahashi, J., Thelen, W.A., Tollett, W., and Trusdell, F.A., 2016, The 20142015 Pāhoa lava flow crisis at Kīlauea Volcano, Hawai' $i$ : Disaster avoided and lessons learned, GSA Today, v. 26, no. 2, available at https:/www.geosociety.org/gsatoday/archive/26/2/ article/i1052-5173-26-2-4.htm.

Public Utilities Commission (PUC), 2018, PUC Initiates Response Plan to Address Shutdown of Puna Geothermal Power Plant on Hawai'i Island: Media release from State of Hawaii available at https://puc.hawaii.gov/wp-content/ uploads/2018/06/PUC-Initiates-PGV-Response-PlanJune-15-2018.pdf.

Raine, H., 2019, Cesspools in Paradise: Ka Pili Kai Kau, University of Hawai'i Sea Grant College Program, available at http://seagrant.soest.hawaii.edu/cesspools-in-paradise/

Richter, D.H., Ault, W.U., Eaton, J.P., and Moore, J.G., 1964, The 1961 Eruption of Kilauea Volcano Hawaii: U.S. Geological Survey Professional Paper 474-D, available at https://pubs.usgs.gov/pp/0474d/report.pdf. 
Richter, D.H., Eaton, J.P., Murata, K.J., Ault, W.U., and Krivoy, H.L., 1970, Chronological Narrative of the 1959-60 Eruption Of Kilauea Volcano, Hawaii: U.S. Geologic Survey Professional Paper 537-E, available at https://pubs.usgs.gov/ pp/0537e/report.pdf.

Scholl, M.A., Ingebritsen, S.E., Janik, C.J., and Kauahikaua, J., 1995, An Isotope Hydrology Study of the Kilauea Volcano Area, Hawaii, U.S. Geological Survey Water-Resources Investigations Report 95-4213, $49 \mathrm{p}$.

Sherrod, D.R., Sinton, J.M., Watkins, S.E., and Brunt, K.M., 2007, Geologic Map of the State of Hawai' $i$, U.S. Geological Survey Open File Report 2007-1009, available at https://pubs.usgs.gov/ of/2007/1089/

Stearns, H.T., and Macdonald, G.A., 1946, Geology and GroundWater Resources of the Island of Hawaii: Territory of Hawaii Division of Hydrography Bulletin 9, 111 p., available at https:// pubs.er.usgs.gov/publication/70160867.
Volcano Watch, 2004, HVO Science Fair Award winners shine: Hawaiian Volcano Observatory, available at https:// volcanoes.usgs.gov/observatories/hvo/hvo_volcano_watch. html? vwid=747.

Wiegener, T.N., Mokiao-Lee, A.U., and Johnson, E.E., 2016, Identifying nitrogen sources to thermal tide pools in Kapoho, Hawai'i, U.S.A, using a multi-stable isotope approach, Marine Pollution Bulletin, v. 103, p. 64-71, available at https://doi. org/10.1016/j.marpolbul.2015.12.046.

Wright, T.L., Chun, J.Y.F., Esposo, J., Heliker, C., Hodge, J., Lockwood, J.P., and Vogt, S.M., 1992, Map Showing LavaFlow Hazard Zones, Island of Hawaii, U.S. Geological Survey Miscellaneous Field Studies Map 2193, available at https:// pubs.er.usgs.gov/publication/mf2193.

Zablocki, C.J., 1977, Self-potential studies in east Puna, Hawaii in Geoelectric studies on the east rift, Kilauea Volcano, Hawaii Island: Hawaii Institute of Geophysics, University of Hawaii, Geothermal Resources Exploration in Hawaii, v. 3, publication HIG-77-15, p. 175-193. 


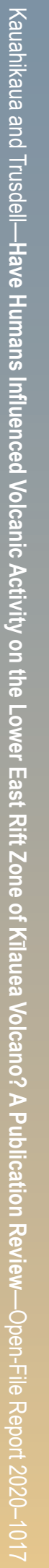

